\title{
"Juicio de amparo" e mandado de segurança. (Contrastes e confrontos.)
}

\author{
Alfredo Buzaid \\ Catedrático de Direito Judiciário Civil na \\ Faculdade de Direito da Universidade de \\ São Paulo.
}

\section{INTRODUÇÃo.}

SUMÁRIO: 1. O "juicio de amparo" e o mandado de segurança são remédios constitucionais. Idéias filosóficas, políticas e religiosas que influiram em sua elaboração. 2. Os antecedentes inglêses: da "Magna Charta" ao "Instrument of Government". 3. O sentimento de desconfiança do colono americano. Defesa do indivíduo contra os abusos do Estado.

1. O juicio de amparo e o mandado de segurança são remédios constitucionais ${ }^{1}$ preordenados à tutela dos direitos subjetivos individuais, ofendidos por ilegalidade ou abuso do poder. 0 primeiro é uma criação original do direito mexicano; o segundo, do direito brasileiro. Êste conta apenas um quarto de século; aquêle tem uma vida centenária, ao longo da qual se aperfeiçoa incessantemente. Ambos constituem garantias jurisdicionais dos

1. A fórmula usada no texto serve para designar uma espécie de ação judiciária que visa a proteger categoria especial de direitos públicos subjetivos. Há um século e meio as Constituições de tipo liberal democrático, estruturando o chamado "Estado de Direito", exaram um rol de direitos do homem e do cidadão; a cada direito subjetivo deveria corresponder necessàriamente uma ação; no entanto, tais decla- 
direitos do homem, exercem função análoga nos países em que foram adotados e guardam cunho nitidamente americano, quiçá sem paralelo no direito comparado.

Mas, para compreender com clareza, a razão por que surgiu a figura do amparo, que goza de indiscutível prioridade sôbre os demais institutos, idênticos ou similares, consagrados no Novo Mundo, é indispensável estudar, primeiro, ainda que em apertada síntese, o conjunto das idéias difundidas nos fins do século XVIII e primórdios do século XIX e a repercussão que produziram nos espíritos dos legisladores mexicanos, sem perder de vista as condições mesológicas do homem que abandona a Europa para se radicar nas terras dêste continente.

No domínio filosófico predominava a concepção jusnaturalista, segundo a qual o homem é titular de direitos absolutos, oriundos da natureza, anteriores e superiores ao Estado; a lei não os criou, limitou-se a reconhecê-los; por isso, se o Estado os of ende, falha em sua missão. A liberdade humana é ilimitada em princípio, enquanto o poder do Estado é limitado ${ }^{2}$.

rações, embora representassem um quadro do direito e da dignidade humanas (FICHTE, Vorrede VII), tinham uma eficácia antes teórica que prática, valendo o seu enunciado como proposição meramente ideológica. A tais direitos era preciso conferir ação adequada para torná-los efetivos. Foi o que fizeram certas Constituições, inserindo, entre os seus mandamentos, regras de direito processual. O estudo da natureza dêsses preceitos suscitou um tema empolgante —o das garantias constitucionais do processo civil, para o qual se voltou particularmente a atenção da doutrina (Cf. LIEBMaN, Diritto Costituzionale e Processo Civile em Rivista di Diritto Processuale, Ano VII, 4, p. 327 e segs.; Couture, Estudios de Derecho Procesal Civil, I, p. 21 e segs.; RENzo Provinclali, Norme di Diritto Processuale nella Costituzione, Milão, 1959, p. 44 e segs.; JosÉ FREDERICO MARQUES, Ensaio sôbre a jurisdição voluntária, S. Paulo, 1959, p. 17 e segs.).

2. CARL SchmitT, Verfassungslehre, 3a. ed., p. 126; DeL Vecchio, Teoria do Estado, trad. brasileira, S. Paulo, 1957, p. 251: “A idéia de que o ser humano possui, por sua natureza, certos direitos, válidos mesmo que a êles não correspondam, ou só imperfeitamente correspondam, as determinações das ordens jurídicas positivas, fulgurou na mente 
No domínio político, o tipo de Estado que se conforma ao jusnaturalismo tem por finalidade a tutela do cidadão contra os abusos do poder. O Estado de Direito, em que se transfunde a ideologia do liberalismo democrático, é o império da lei, que cria como que uma harmonia preestabelecida entre os seus preceitos e a garantia da liberdade ${ }^{3}$. Submetido à ordem jurídica, o Estado de Direito supõe a distinção entre os poderes legislativo, executivo e

humana, como é sabido, desde tempos muito remotos, e foi formulada, em perspícuas expressões principalmente por obra da filosofia estoica e da Jurisprudência romana, como, desde então até nossos dias, no decurso dos séculos, por vêzes inspirando-se nos dogmas da religião cristã, outras vêzes na só luz da razão natural." Marcello CaEtano, Curso de Ciência Política e Direito Constitucional, 3. a ed., Coimbra, 1959, vol. I, p. 273, também escreve: "No século XVIII a crença no direito natural manifestou-se sobretudo na sua modalidade individualista. Todo homem, pelo mero fato do nascimento, seria titular de interêsses sagrados que os outros homens, individual ou coletivamente considerados, teriam o dever de respeitar para assegurar o respectivo desenvolvimento. Êsses interêsses traduzir-se-iam em direitos individuais naturais, anteriores e superiores à sociedade política. 0 Estado não os confere; reconhece-os. A sociedade não os cria; declara-os. Não há, pois, uma lei que manifeste a vontade geral de atribuir tais direitos ao homem; desde que êstes provém da natureza, a vontade humana nada pode e apenas à razão cabe descobrílos para os enumerar ou declarar. O legislador, mesmo constituinte, deve acatamento e respeito a tais imperativos da natureza pois o Estado, ao constituir-se, tem de contar com êles e de partir dêles".

3. Luis Legaz y Lacambra, El Estado de Derecho en la Actualidad, Madrid, Ed. Reus, 1934, p. 13 e segs. Para êste autor o direito natural democrático é aquela corrente do jusnaturalismo que, desprendendo-se da fundamentação tradicional teística, adota como ponto de partida o conceito de personalidade humana como esfera de direitos e de liberdades que não só são "naturais." e independentes de outorga pelo Estado, senão que constituem o limite "natural" da ação dêste e para cuja melhor defesa se instituiu (op. cit., p. 19). Segundo ANTonio Josḱ Brandão, Sôbre o Conceito de Constituição Política, p. 58: “O Estado-de-Direito, pela origem e finalidade históricas, não se inspirou no desejo teórico de reunir sintèticamente numa Constituição política ótima os princípios de tôdas as Constituições políticas boas; obedeceu apenas ao desejo de aliviar o homem de tôda a espécie de absolutismo gover- 
judiciário. O legislador não deve administrar. $O$ administrador não deve legislar. Quando o legislativo e o executivo se reunem nas mãos de um só, não há democracia senão despotismo ${ }^{4}$. A lei não há de ser a vontade de um ou de muitos senão algo de racional, dotado de generalidade; não voluntas senão ratio ${ }^{5}$.

No domínio religioso, depois das lutas sangrentas que sacodem a Europa por largo tempo, o século XVII assinala o triunfo do princípio da liberdade de consciência, não sujeita ao tribunal dos homens, mas ao julgamento de Deus; difunde-se a convicção que a liberdade de pensamento, não é um direito concedido ao cidadão pelo Estado, mas um direito nascido com o homem e por isso natural, superior e inviolável ${ }^{6}$.

2. Enquanto medravam estas idéias na Europa continental, evoluindo progressivamente até culminarem na famosa Declaração dos Direitos do Homem e do Cidadão,

nativo. É esta aspiração a base mestra da sua construção." Para Marcello Caetano, Curso de Ciência Política e Direito Constitucional, Coimbra, 1959, I, p. 281, "há duas concepções correntes do Estado de Direito: uma material, jusnaturalista, realização de certo conceito de Justiça; outra formal, positivista e, portanto, simples instrumento ao serviço de qualquer conceito de Justiça, cabendo-lhe melhor a designação de Eistado de legalidade (Gesetzesstaat)."

4. Montesquieu, De l'Esprit des Lois, Liv. XI, cap. VI; LockE, The Second Treatise of Government, cap. XII.

5. Schmiтt, Verfassungslehre, p. 139, observa que a burguesia, na luta por sua liberdade e por seu Estado de Direito, adotou uma concepção de lei que assenta em velha tradição européia e que passou descle a Filosofia Grega à Idade Moderna através da Escolástica. Aristóteles, Política, IV, 4, 4, já havia distinguido a democracia sob o império da lei, daquela em que prevalecem as resoluções populares. Em S. ToMás é rationis ordinatio, isto é, lex est aliquid rationis (Summa, 1a. 2ae., Q. XC, Art. 1). Segundo a concepção dos absolutistas, auctoritas, non veritas facit legem (HoBBes, Leviathan, cap. 19). Para KANT é despótico o Govêrno que ao mesmo tempo assume funções de legislador e pratica atos de Govêrno (Zum ewigen Frieden, II, p. 199).

6. Jellinex, La Déclaration des Droits de L'Homme et du Citoyen, trad. franc. de Georges FARdis, Paris, 1902, p. 77 e segs. 
feita pela Revolução Francesa em 26 de agôsto de 1789, a Inglaterra já se antecipava, de vários séculos, na conquista das liberdades individuais. Um dos traços marcantes de suas instituições políticas era o primado da lei ${ }^{7}$. Já nos albores do século XIII, para conter os desregramentos de JoÃo Sem Terra, reuniram-se condes e barões e exigiram do Rei a Magna Charta Libertatum, outorgada a 19 de junho de $1215^{8}$. Em era posterior, especialmente sob o reinado de Carlos $I$, que se alheou da nobreza e intentou abalar a autoridade da lei, reaviva-se o anseio de liberdade dos inglêses, cujos fidalgos, inspirados por HAMPDEN, desencadeiam o movimento de opinião, que obtém a Petitions of Rights de 1627; no Instrument of Government, tido como primeiro e único documento constitucional da Inglaterra ${ }^{9}$, garante-se expressamente a liberdade de consciência, no art. 38: "Tôdas as leis, estatutos, ordenações e cláusulas em qualquer lei, estatuto ou ordenança, em contrário à liberdade de consciência, serão considerados írritos e nulos". Coke sustenta com vigor que o juiz pode declarar nula uma lei, ou porque seja contra a razão e o direito natural, ou porque usurpe prerrogativas reais ${ }^{10}$.

Nesses documentos políticos prescreve-se a proibição de suspender leis, estabelecer tribunais de exceção, impor penas cruéis e aumentar impôsto sem autorização legal; assegura-se juri imparcial, liberdade eleitoral e convocação regular do Parlamento. Mas, como observa JellineK,

7. DICEY, Introduction to the Study of the Law of the Constitution, 9a. ed., Londres, 1956: "This peculiarity of our polity is well expressed in the old saw of the courts, "La loi est le plus haute inheritance, que le roi ad; car par la loi il même et toutes ses sujets sont rulés, et si la loi ne fuit, nul roi, et nul inheritance sera", (p. 184).

8. Pontes DE Miranda, História e Prática do "Habeas Corpus", Rio, 1916, p. 10 e seg..

9. JELlineK, Allgemeine Staatslehre, 3a. ed., Berlim, 1922, p. 512.

10. Cf. MaItland, The Constitutional History of England, Cambridge, 1950 , p. 301 . 
nada disso representa direitos para os indivíduos, antes deveres para o Govêrno. É que as leis daquela época ainda não haviam chegado a reconhecer um direito eterno e natural do homem; ao contrário, fundavam-se em direito advindo dos ancestrais, os antigos direitos incontestáveis do povo inglês ${ }^{11}$.

3. Os que emigram para a América, a fim de se libertarem da estrutura econômica e das perseguições religiosas tão freqüentes na Europa, conservam a lembrança das leis que lhes regeram os atos, mas levam também, no fundo de suas almas, embora obscurecido pelo andar dos tempos, o sentimento de confiança na organização social a que pertenciam, fundada na vontade sábia e omnipotente de Deus. Encontrando-se já no Novo Mundo, invade-lhes a idéia de desconfiança ${ }^{12}$ pois o estado de liberdade em que se moviam discretamente nos fins da idade média, se dilata até o ponto extremo de terem de lutar por êle para garantí-lo em tôda a sua plenitude. Se a liberdade no domínio religioso traduz o supremo ideal da coexistência humana, na esfera econômica representa a emulação na conquista das riquezas e, no campo político, a possibilidade de a maioria eventual do Congresso sufocar valiosas conquistas e ofender princípios tradicionais. Tudo estava, pois, em fazer com que a liberdade não engendrasse os próprios germes de sua destruição. $O$ es-

11. JELLINEK, La Déclaration, cit., p. 50 e segs.

12. Legaz y Lacambra, El Estado de Derecho en la Actualidad", p. 31: "Pero la Edad Media muere con el nacimiento de un nuevo "tipo de hombre" diferente del que había predominado hasta entonces. Este nuevo tipo de hombre está cualificado por esta característica: la desconfianza. El hombre medieval tenía un sentido confiado y optimista, sabiéndose seguro dentro de los cuadros sociales en que se movía; su aegre adaptación al orden de cosas, considerado como un orden de cosas querido por Dios, no tenía nada de la resignación que engendra el resentimiento. En el hombre moderno nace una fe nueva, que es la fe en el progreso, pero al mismo tiempo se va convirtiendo en átomo de un inmenso organismo en desarticulación. La desconfianza es ahora un elemento constitucional humano." 
tado de espírito do imigrante, cujo fôro intimo era povoado de tais idéias, havia de levá-lo a preocupar-se em construir, no novo mundo, um tipo de democracia, na qual a liberdade, em suas diferentes manifestações, não fôsse apenas uma declaração programática e ideológica, antes encontrasse uma tutela efetiva e real em conformidade com a concepção jusnaturalista, que considerava os direitos do homem um fenômeno anterior e superior ao Estado.

Desconfiando, pois, que o Estado pudesse conculcar ou negar a liberdade, procura um sistema caracterizado pelo império da lei, contra o qual não prevalecesse nem mesmo a vontade geral do povo; e consegue, de fato, realizá-lo, ao estabelecer, na Constituição, como pacto fundamental da sociedade política, o conjunto dos direitos do homem e do cidadão e ao conferir, desde logo, meios idôneos para assegurar o seu pleno gôzo e exercício.

\section{Capítulo I}

\section{A Declaração dos Direitos do Homem e do Cidadão nos Estados Unidos e na França.}

SUMÁRIO: 4. Origem americana da Declaração de Direitos. $A$ análise de JELlineK. 5. Prioridade histórica dos americanos. Idéias religiosas e filosóficas do colono. A liberdade de consciência. 6. Paralelo entre a declaração americana e a francesa.

4. Ninguém põe em dúvida a importância política da Declaração francesa dos Direitos do Homem e do Cidadão; trata-se de um dos mais notáveis documentos da história moderna, cuja repercussão logrou êxito universal. Os autores procuram explicar a origem das idéias 
que influiram na sua elaboração. Uma delas, pode dizer-se claramente francesa e revolucionária, filiando-se à obra de Rousseau. Paul Janet pergunta: "É necessário provar que tal ato não provém de Montes@uueu senão de J. J. Rousseau? É o próprio ato da declaração coisa distinta do contrato firmado entre todos os membros da comunidade segundo as idéias de Rousseau? Não é o enunciado das cláusulas e condições dêste contrato ${ }^{13}$

Criticando esta doutrina, observa JellineK que difìcilmente se pode compreender que um autor, que tão bem conhece o contrato social, possa partilhar nessa matéria a opinião corrente. $O$ contrato social se reduz a uma cláusula única, isto é, a alienação à coletividade de todos os direitos do indivíduo. Este não conserva sequer um átomo de direitos, no momento em que entra no Éstado. Tudo que faz, recebe da vontade geral que, de per si, determina seus limites, mas não deve nem pode ser restringida juridicamente por outro poder. Nem a propriedade pertence ao indivíduo senão por concessão do Estado; o contrato social torna o Estado senhor de todos os bens dos seus membros, que continuam a possuí-los sòmente como depositários do bem público. A liberdade cívica fica simplesmente no que sobeja ao indivíduo, após a determinação dos seus deveres. A concepção de um direito originário que o homem levaria para a sociedade e de que se utilizaria como limitação jurídica do poder soberano, Rousseau expressamente a repeliu ${ }^{14}$.

13. PAUL JANet, Histoire de la Science Politique, p. 457 e seg..

14. JeLliNeK, La Déclaration, cit., p. 9 e segs.. Êste autor invoca os seguintes textos da obra de Rousseau, Du contrat social, para fundamentar a sua asserção: "Ces clauses, bien entendues, se réduisent toutes à une seule: savoir, l'aliénation totale de chaque associé avec tous ses droits à toute la communauté" ( $I, 6)$. "De plus, l'aliénation se faisant sans réserve, l'union est aussi parfaite qu'elle peut l'étre et nul associé n'a plus rien à réclamer" $(I, 6)$. "Car l'État, à l'égard de ses membres, est maître de tous leurs biens par le Contrat social” (I, 9). ".... Les possesseurs étant considérés comme dépositaires du bien public" (I, 9). Schmit, Verfassungslehre, 3a. ed., p. 157 diz que "a 
Para Jellinek, ao contrário, a primeira exposição de um rol de direitos do homem foi elaborada pelos Estados Unidos em 4 de julho de 1766, ou antes, foi a declaração de Virgínia e de outros Estados particulares da América que constituíu a fonte mais antiga e que serviu de base à proposta de LAfayetTe na Assembléia Geral francesa. Embora as Constituições de Connecticut de 1602 e de Rhode Island de 1603 pareçam ser as mais remotas Constituições escritas, no sentido moderno da palavra, coube indubitàvelmente à Virgínia o mérito de ter adotado uma Constituição na Convenção de Williamsburg de 1776 , em cujo preâmbulo figura uma solene declaração de direitos, de que foi autor George Mason ${ }^{15}$.

história dos direitos fundamentais começa pròpriamente com as declarações que os Estados americanos formularam no século XVII, ao se tornarem independentes da Inglaterra."

15. JeLlineK, La Déclaration, cit., p. 18. Esta teoria suscitou viva controvérsia, especialmente em França. Boutmy, Études Politiques, Paris, 1907, p. 119 e segs., contesta a idéia fundamental de JeLLINEK, vendo na Declaração dos Direitos o eco do pensamento de publicistas franceses do século XVIII. Depois de reconhecer que JELLINEK tem "une raison excellente de contester que Rousseau ait agi sur la Déclaration des droits" (cap. 130), observa que "Vers 1760, il existait concurrement en France, en Hollande, en Angleterre et aux États-Unis, et une manière de raisonner et une nature particulière d'arguments qui n'étaient propres à aucun de ces pays. Chacun développait à sa guise, et suivant son génie, les idées qu'il tirait de ce trésor commun. Ainsi, les analogies que l'on observe entre telles Déclarations américaines et la Déclaration française de 1789 ne doivent pas nous porter à les rapprocher l'une de l'autre, mais à les rapprocher toutes deux d'un même modèle." (p. 137). E ajunta: "Il n'y a donc pas lieu de supposer que tout ce qui se ressemble dans les deux documents provient de ce que notre Déclaration des droits a copié ou imité plus ou moins les Bills des droits des États-Unis. Chacun des deux textes a puisé, non dans l'esprit de son pays, mais dans l'esprit de son temps, des conceptions presque identiques qu'il exprimait en style abstrait, c'est-à-dire à la mode du XVIIIe siècle. Nul emprunt ne peut être décelé d'un document à l'autre." (p. 138). O tema é retomado hoje em dia por Burdeau, Traité de Science Politique, III, p. 114 e segs., que diz: "Certes, le débat est intéressant pour l'éttablissement d'une 
5. A importância desta última concepção não está apenas em evidenciar a prioridade histórica do documento americano e sua influência sôbre a declaração francesa, mas principalmente em investigar as razões mais profundas que condicionaram a formação da estrutura política dos Estados Unidos, tornando-a um modêlo a que se compuzeram as demais nações do Novo Mundo. Era preciso efetivamente saber se a declaração americana dos direitos do homem surgiu como uma legítima aspiração

filiation entre les idées politiques, mais du point de vue historique il est superflu, puisque la chronologie fixe l'antériorité des déclarations américaines. Le système ayant été inauguré en Amérique, il y aura lieu de rechercher seulement l'enrichissement que lui a valu son utilisation par les constituants français. Nous verrons alors que cet apport n'est pas mince. Lorsque, de 12 juin 1776, l'assemblée de la Virgine, réunie à Williamsbourg, vota la déclaration qui devait, plus ou moins fidèlement suivie de modèle aux autres colonies, ce n'était pas la première fois que les colons consignaient solennellement, dans un document officiel, la liste des droits qu'ils considéraient comme intangibles. Les diverses législations coloniales sont, dès le XVIIe siècle, remplies de déclarations de ce genre. Mais, à vrai dire, ces textes étaient devantage des garanties prises contre les autorités politiques que l'indication d'un système général de gouvernement. Ce caractère subsiste d'ailleurs dans les déclarations de l'époque de la conquête de l'indépendance. Chacun de leurs articles présente une signification très concrète, parce qu'il est lié à la préoccupation de protéger telle liberté ou telle pratique définies. Les dix premiers émendements à la constitution fédérale qui forment le bill of rights des États-Unis procède d'une intention analogue. "J'espère, disait JEFFERSON avant leur adoption, qu'une Déclaration des droits sera redigée pour protéger le peuple contre le gouvernement fédéral, comme il est déjà protégê dans la plupart des cas contre le gouvernement des États" Il résulte de cette conception que les premières déclarations américaines ont un caractère negatif, qui cadre sans doute avec leur individualisme, mais que donne à cet individualisme même une signification si absolue que l'ḱtat apparaît, en face de l' individu, comme un mécanisme subordonné, volontiers abusif e toujours suspect. Dans ces conditions, l'idée de droit qui se dégage de semblables déclarations n'est pas propice au développement d'une philosophie politique de grande envergure. Il est bien vrai, sans doute, que les Américains n'ignoraient pas les leçons de l'École de droit naturel, ils admettaient l'existence d'une loi supérieure aux législations posi- 
dos povos que cultivavam as idéias nela consagradas, ou se foi apenas uma trasladação por cópia de um tipo ideal de super-estrutura que a nação recebeu a um tempo com alegria por traduzir um sonho e com estupor por estar divorciada da realidade. Acha Jellinek que os americanos edificaram seu regime social e político em 1776 sôbre bases já existentes entre êles há muito tempo; os franceses, não; o que na América era a conseqüência lógica de uma lenta evolução que coroa um século de história e serve assim para consolidar o edifício, em França constitui um agente de destruição do passado ${ }^{16}$.

Embora haja acentuada semelhança entre o Bill of Rights dos inglêses e a declaração americana, ela é, na realidade, antes formal que substancial. Fiéis ao pensamento jusnaturalista, os americanos se preocuparam, antes de tudo, em traçar a linha demarcatória entre o indivíduo e o Estado. Este ponto de partida assinala uma diferença fundamental, que permite atribuir a cada documento valor autônomo. Para os americanos, o indivíduo não deve ao Estado, antes à sua qualidade de homem, os direitos que possui, direitos que são inalienáveis e invioláveis ${ }^{17}$; todos os homens nascem absolutamente livres e se êles se constituem em sociedade polìticamente organizada, não é para abdicar de direitos inatos e naturais senão para garantir a segurança individual e a

tives; mais ce n'est pas tant ce droit naturel ni cette loi supérieure dont ils entendaient formuler les règles dans leurs déclarations que les droits définis dont jouissaient les Anglais, dont Locke avait établi le fondement philosophique et BLAKSTONE déterminé la nature juridique. C'est avec cette portée restrainte que les colonies devenues indépendantes ont envisagé le droit naturel dans leurs déclarations. Malgré leur apparente généralité, aucune ne prétend édicter les bases d'un système social universellement valable; elles ne se sont pas souciées de faire grand, mais de faire efficace."

16. JeldiNeK, La Déclaration, cit., p. 46.

17. JeLlinek, La Déclaration, cit., p. 50 e seg.; BatTaglini, Contributi alla Storia del Controllo di Costituzionalitá delle Leggi, p. 33 e seg.; BatTaglia, Nuovi Scritti di Teoria dello Stato, p. 184. 
prosperidade pública, nomeadamente para tutelar a liberdade de consciência ${ }^{18}$.

Alguns eloqüentes episódios da histónia americana, como a fundação de Salem, em Massachussets, o abandono desta cidade por Roger Williams, que lança as bases de Providence e ainda a criação de Aquednek em Rhode Island, atestam que os seus habitantes renunciaram ao convívio social para não sacrificar a liberdade de consciência; repontando no meio em que viviam sentimento de intolerância religiosa por parte dos que esqueceram as perseguições sofridas na mãe-pátria, preferiam fundar novas cidades, onde todos pudessem professar livremente o culto religioso ${ }^{19}$.

6. Formada a convicção de que há direitos do homem que precedem à organização do Éstado e do qual são independentes, prossegue Jellinek, fácil foi afirmar, na ordem política, a sua inviolabilidade pelas leis civis. Em célebre obra de JaMes Otis que aparece em Boston em 1764 se sustentou com ênfase: "Pode vir dia em que o Parlamento declarará nula e de nenhum efeito tôda carta americana; em tal dia, porém, os direitos dos colonos como homens e como cidadãos, êsses direitos naturais inerentes à sua qualidade, inseparáveis de suas frontes, não serão atingidos. As Cartas podem variar; êsses direitos durarão até o fim do mundo" ${ }^{20}$. Enfim, conclui Jellinek, a 14 de outubro de 1774, o Congresso reunido em Filadélfia e representando as doze colônias, votou uma Declaração de Direitos, em que se dizia que os habitantes da América do Norte têm prerrogativas que

18. Jeluinek, La Déclaration, cit., p. 63. Sôbre a concepção jusnaturalista, ver entre os autores nacionais: ARY FLORÊNCro GUIMARÃES, Liberdades Fundamentais da Pessoa Humana em face do Estado, p. 34; Machado Paupério, Teoria Geral do Estado, 3a. ed., p. 332 e segs.

19. Sôbre as idéias que influiram na elaboração das várias declarações americanas, ver: Alcino Pinto FALCÃo, Constituição anotada, vol. II, p. 21 e seg.

20. Cf. JellineK, La Déclaration, cit., p. 84. 
lhes pertencem em virtude de direito imutável da natureza, da Constituição inglêsa e das suas próprias Constituições ${ }^{21}$. De lá até à declaração de Virginia parece não haver senão um passo e, no entanto, há todo um abismo que separa êsses dois documentos. A Declaração de Filadélfia é um portesto; a de Virgínia, uma lei ${ }^{22}$. A diferença entre o sistema americano e o francês está em que "os americanos proclamaram como um patrimônio eterno, comum a todos os povos livres, os direitos que êles já possuiam. Os franceses, ao contrário, querem dar o que êles ainda não têm, instituições que devem corresponder aos princípios gerais. Na América as instituições positivas precedem ao reconhecimento solene dos direitos individuais; na França, sucedem" 23 .

Qualquer que seja a apreciação sôbre o valor da Declaração francesa, a verdade é que "ela oferece, como acentua DeL Vecchio, a todos os povos da Europa, que ainda estavam sujeitos ao regime absoluto, um modêlo teórico da liberdade, em que se inspiraram, melhor do que em qualquer outro, para suas reivindicações positivas, associando, daí por diante, a idéia de um govêrno liberal à de uma determinação fundamental dos direitos do cidadão. $\mathrm{E}$ pelo menos uma parte dos princípios da Declaração foi aceita paulatinamente nas Constituições dos modernos Estados mais adiantados" 24 .

21. SToRy, Commentaries, I, p. 134.

22. JELLINEK, La Déclaration, cit., p. 87.

23. JeLLINEK, La Déclaration, cit., p. 91.

24. Dex, Vecchio, Los Derechos del Hombre y el Contrato Social, Madrid, Ed. Reus, p. 126; MIRKINE-GudiZÉvitch, Les Constitutions Européennes, Paris, 1951, ‥ 127 e seg., dá notícia da apreciação de JELLINEK sôbre os antecedentes americanos da Declaração francesa, reconhecidos por escritores franceses modernos, que lembram palavras do relator da Comissão de Constituição, Arcebispo de Bordeus, a 28 de julho de 1789: "Cette noble idée, conçue dans un autre hémisphère, devait de préférence se transplanter d'abord parmi nous. Nous avons conecuru aux événements qui ont rendu à l'Amérique septentrionale la 


\title{
Capítulo II
}

\section{Garantias de direitos individuais e defesa da Constituição.}

\author{
SUMÁRIo: 7. Direitos do indivíduo e garantias Constitu- \\ cionais. 8. Evolução histórica. 9. A posição do judiciá- \\ rio. 10. Reciprocidade entre a Constituição e os indiví- \\ duos. Defesa dos indivíduos e defesa da Constituição. 11. \\ "Juicio de Amparo" e mandado de se.gurança.
}

7. A solene declaração dos direitos fundamentais significa, no entender de Schmid, o estabelecimento de princípios sôbre que assenta a unidade política de um povo e cuja vigência se reconhece por isso como seu pressuposto mais importante; dá-lhe, pois, na expressão de Smend, a unidade do Estado ${ }^{25}$. Tais direitos dizem-se individuais, porque aludem à pessoa, são inerentes ao homem e qualificam a sua natureza, enquanto coexistem socialmente dentro do Estado. Denominam-se direitos individuais, definiu Alcorta, os que constituem a personalidade do homem e cujo exercício lhe corresponde exclusivamente, sem outro limite que o do direito recíproco. . Ainda que elementos da personalidade do ho-

liberté; elle nous montre sur quelles principes nous devons appuyer la conservation de la nôtre; et c'est le Nouveau-Monde, où nous n'avions autrefois apporté que des fers, qui nous apprend aujourd'hui à nous garantir du malheur d'en porter nous-mêmes"; e conclui que "Rédigée en français - langue universellement répandue au XVIIIe siècle formulée en termes beaucoup plus abstraits que les textes américains, la Déclaration des Droits devait faire véritablement le tour du monde. Elle allait influencer les nations, les peuples et les hommes. Elle allait traverser l'océan pour soulever contre l'Espagne l'Amérique latine. La Déclaration des Droits de l'Homme et du Citoyen de 1789 reste, dans l'histoire politique et constitutionnelle moderne, le texte "classique". imité, adopté et suivi"

25. Sснмтт, Verfassungslehre, cit., p. 161. 
mem, manifestam-se os direitos individuais na própria pessoa, nas coisas e nas ações. Na pessoa, em todos os atos que se referem à liberdade individual; nas coisas enquanto a seu uso e disposição exclusivos, meios de adquirir, de existência e de bem estar; e enquanto às ações relativamente a tôdas as manifestações da palavra oral ou escrita e a todo o exercício que lhe toque ${ }^{6}$. Este conceito do ilustre publicista argentino coincide substancialmente com o que foi formulado no Brasil por Pimenta Bueno: "Os direitos individuais, que se podem também denominar naturais, primitivos, absolutos, primordiais ou pessoais, são faculdades, as prerrogativas morais que a natureza conferiu ao homem çomo ser inteligente; são atributos essenciais de sua individualidade, são propriedades suas inerentes à sua personalidade: são partes integrantes da entidade humana" 27.

O que ressalta, nos conceitos dêsses autores, como em geral dos que tratam ex professo do tema ${ }^{28}$, é um

26. Alconta, Las Garantias Constitucionales, 1881, p. 7 e seg..

27. Pimenta Bueno, Direito Público Brasileiro, 2a. parte, p. 390.

28. BIELsA, Estudios de Derecho Publico, III, p. 367 pergunta: "Que é uma garantia? Em que sentido emprega esta palavra a Constituição? Podem propor-se várias questões a estas perguntas: $\tilde{E}$ um protesto de respeito a uma situação individual civil ou política? $\hat{\mathrm{E}}$ uma promessa de proteção efetiva em caso de ser lesado o direito? E própria norma obrigatória para todos (jus cogens) ?" E mais adiante estabelece um confronto entre direito e garantia: "Entre los derechos y las garantías existe, desde luego, una diferencia formal. Mientras los derechos o declaraciones de derechos importan el reconocimiento de atributos de orden político o jurídico que la persona tiene, las garantías son normas positivas - y, por tanto, expresadas en la Constitución o en la ley -, que asseguran o protegen un derecho determinado. La declaración de derechos se hace en el momento causal; las garantías se instituyen en el orden formal. Decimos que la garantía puede establecerse en la Constitución y en la ley; la diferencia entre una y otra se advierte al punto, pues no sólo es cronológica, sino también de grado. La garantía constitucional protege y asegura el derecho frente al mismo poder legislativo, y con mayor razón frente a los otros poderes; no así la garantía legal, pues ella es una autolimitación del Estado, cuando se 
elemento comum, antes negativo que positivo. Não se impõe que o Estado pratique qualquer ato senão que se abstenha de intervir no domínio da liberdade, criando-lhe restrições ou suprimindo-a. O ideal de definir os direitos do homem foi inegàvelmente uma das mais importantes conquistas do século XVII, mas a declaração estava banhada de um certo romantismo político, de efeitos mais ilusórios que reais; fôrça era provê-la de meios aptos a alcançar a sua plena efetivação perante um dos poderes do Estado, não sujeito aos demais. A declaração de direitos desprovida de garantias teria apenas a virtude de um manifesto político com promessas sedutoras, dificilmente cumpridas pelos detentores do poder; seria ao mesmo tempo uma fonte de alegria e de desengano. A sua fôrça estaria no esplendor de ideais profundamente humanos que difundiria; mas a sua fraqueza, na ausência de um instrumento idôneo para a sua realização ${ }^{29}$.

8. Surgiu daí o dualismo: direitos e garantias. Aquêles foram elevados à eminência constitucional; mas aos direitos deve corresponder a tutela e o grau de sua reação há de medir-se pela intensidade da ofensa. O Estado, se quer cumprir a sua finalidade, precisa subministrar recursos idôneos para conseguir a mais completa proteção dos direitos individuais, A solução de tão grave problema, encontrou-a o direito norte-americano, aplicando dois principios fundamentais: a) a Constituição é a lei suprema, definidora dos direitos, acima da qual não há nenhuma outra; é o chamado princípio da supremacia constitucional; b) qualquer lei ou ato de autoridade, avesso à constituição, é nulo, sendo conferido à parte lesada o

trata de su propia actividad (tal sería una ley que responsabilizara al Estado por sus actos). Por lo demás, la garantía constitucional es operativa, aun a falta de ley que la haya reglado en el ordenamiento positivo". (p. 370). Ver ainda PONTES DE MIRANDA, Comentários à Constituição de 1946, 2a. ed., vol. IV, p. 13 e segs.

29. Cf. Alcino Pinto FalCão, Constituição anotada, vol. II, p. 25. 
direito de recorrer ao Poder Judiciário, a fim de se subtrair ao efeito do ato inconstitucional.

Já no direito romano houve a preocupação de proteger a liberdade como um dos mais elevados bens do homem. O livro 43, título 29 do Digesto (De Homine Libero Exhibendo) compendia várias regras, pelas quais o pretor concedia o interdito para amparar a liberdade.

Dig. 43, 29.1,\$1: Hoc interdictum proponitur tuendae libertatis causa, videlicet, ne homines liberi retineantur a quoquam.

Debalde se hão de procurar quaisquer cartas constitucionais em direito romano. Havia, como acentuou Brond, um alto senso de civilidade, humanidade e decôro que impunha a abstenção de excessos e abusos. Contudo, não faltaram leis e princípios que poderiam considerar-se como os albores do reconhecimento jurídico da personalidade do homem. Notável é aquela dúzia de leis comiciais de provocatione, da legendária Lex Valeria de 509 antes de Cristo à Lex Antonia de 44 antes de Cristo, que objetivavam defender o civis contra condenaçóes ou providências do magistrado, tidas como injustas e também a disposição da Lex Julia de vi publica, que punia a prepotência e exercida contra o civis por parte de quem fôsse aliqua potestate praeditur: PavL, Sent, 5.26.1.30.

30. BIondo BIond, Il Diritto Romano Cristiano, vol. II, p. 344. Para Felice Battaglia, Nuovi Seritti di Teoria dello Stato, p. 178, "Si parla di un diritto naturale, fondato sulla natura delle cose, si parla persino di un diritto comune a tutti, ne parlano Aristotele e Cicerone, lo teorizzano gli stoici e i giureconsulti romani, ma evidentemente esso ha un significato oggettivo, non soggettivo, non si estrinseca in attribuzioni ed inerenzedi singoli, e tanto meno in facoltà e pretese loro verso l'ente politico, il quale, nella classicità, permane supremo valore nell'ordine etico, in cui tutto si compendia, morale e religione, economia e diritto, risolvendosi e perdendosi ogni autonomia dell'individuo. Questo se è cittadino, cittadino prima che uomo, e cittadino vuol dire soldato e magistrato, non è mai avvertito in sé e per sé." 
$\mathrm{Na}$ idade média deram os inglêses o exemplo de sua altivez sempre que houve ameaça aos direitos fundamentais do gênero humano, que se classificavam, conforme a síntese de Rui Barbosa, em três categorias: segurança, liberdade, propriedade. Ésses direitos, preexistentes, segundo sir EDWARD CoKe, "nas leis fundamentais de Inglaterra", tiveram a sua grande consagração na Magna Carta, em 1215, depois no ato de Henrigue III, na confirmatio cartarum de Eduardo I, na petição de direitos sob Carlos I, no ato do habeas corpus sob Carlos II e, afinal, sob GuILHERME e MARIA, em 1688, no bill of rights ${ }^{31}$.

Nos tempos modernos a declaração de direitos formulada pela França em 1789 constitui um documento de elevada cultura política tendente a preservar o valor da criatura humana; todavia não conferiu, para a proteção de tais direitos, um meio adequado, pronto e eficaz, apto a fazer cessar a ilegalidade ou abuso de poder. Afirmações teòricamente perfeitas, mas destituídas de tutela judicial imediata, passam para a história da humanidade como o sonho de uma frustrada realidade, quando deveriam ser de fato a realização de um sonho auspicioso. Elas vinham imbuídas de acentuado otimismo político, fundado na bondade intrínseca da criatura humana; mas cedo se desvaneceram as esperanças, quando as assembléias populares, ditas democráticas ou os golpes de fôrça, implantando o despotismo, sacrificavam os direitos fundamentais da liberdade e da vida.

9. O quadro de tal direito público não podia satisfazer às exigências da nova civilização, surgida na América, que, ciosa dos direitos fundamentais do homem, julgou necessário instituir meios eficazes de sua proteção. Os poderes Iegislativo e executivo não podiam exercer tal função, porque êste, por inclinação natural, tende a ser

31. RuI BARBosa, Comentários à Constituição Federal Brasileira, vol. 5, p. 186. Sôbre a origem popular do Poder na Idade Média, ver Marcello Caetano, op. cit., I, p. 221. 
omnipotente e aquêle, por contingência própria de sua estrutura, está sujeito a oscilações e é impotente para conter os abusos do outro poder. Dos três poderes do Estado, um há que é o mais fraco na fôrça e o mais forte na autoridade de suas decisões: o judiciário ${ }^{32}$. Desde tempos imemoriais confiaram-lhe os homens a solução dos litígios, porque, isento de parcialidade, podia compor os litígios na ordem privada. Dotados de tais qualidades, por que lhe subtrair o poder de resolver os conflitos entre os indivíduos e os poderes do Estado, principalmente depois que êste se tornou Estado de Direito? Por que lhe não atribuir a competência para dirimir a controvérsia nascida de abuso ou desvio de poder? A ampliação de suas atribuições não haveria de conduzir a uma judicialização da política, mas a uma politicização da justiça ${ }^{33}$. Os americanos do norte inauguraram notável experiência política, fundada no princípio de que nenhum dos poderes é soberano; soberano é só o povo, do qual emanam os três poderes, harmônicos entre si e limitados em suas atribuições pela discriminação constitucional. Os excessos praticados pelo legislativo e pelo executivo, violadores de direitos individuais assegurados pela Constituição, podem ser anulados pelo Judiciário ${ }^{34}$, ao qual se atribuiu a competência de declarar a inconstitucionalidade de leis e de atos. Este contrôle representa o coroamento do Estado de Direito ${ }^{35}$.

10. Entre a Constituição e os indivíduos há um nexo de reciprocidade. A Constituição protege os indivíduos,

32. Ver Alfredo Buzaid, Da Ação Direta de Declaração de Inconstitucionalidade no Direito Brasileiro, p. 35 e segs..

33. Schmitt, La Defesa de la Constitución, p. 33; Hector Fix Zamudio, La Garantía Jurisdicional de la Constitución Mexicana, p. 88; Manuel Garcia Pelayo, Derecho Constitucional Comparado, p. 113.

34. Cf. BenJamin F. WRIGHT, The Growth of American Constitutional Law, p. 35 e segs..

35. CAPPELLETTI, La Giurisdizione Costituzionale delle Libertá, p. 133; ZaMudio, op. cit., p. 60. 
conferindo-lhes as garantias necessárias à satisfação dos direitos. Os indivíduos, fazendo valer em juízo os seus direitos violados por ilegalidade ou abuso de poder, preservam, por via indireta, a autoridade da Constituição, porque a proteção não ocorre senão por iniciativa e obra do particular. A ofensa à Constituição pode dar-se por ato privado ou do poder público. A primeira é de mínima repercussão e os seus males são reparados por diferentes modos. A segunda, ao contrário, fere profundamente tôda a sociedade, que por isso mesmo deve reagir com dobrado vigor, pois dos que detêm o poder há de esperar-se o exemplo do cumprimento dos imperativos constitucionais. Ora, escreve Romirez, se a organização que institui a lei Suprema pudesse ser violada impunemente, os preceitos constitucionais não passariam de preceitos teóricos ou de mandamentos éticos. Não é possivel aceitar tal coisa; se alguma lei deve ser cumprida e observada, espontânea ou coercitivamente, é a lei suprema ${ }^{36}$.

Dificilmente se pode prevenir a ofensa à Constituição; por via de regra, o que se procura, depois da violação, é obter a reparação do direito lesado. Mas não se há de excluir a hipótese de ofensa sem dano, notadamente quando as suas conseqüências ainda não atingiram a esfera jurídica dos indivíduos. Cuida-se aí de defesa verdadeiramente constitucional destinada a conter os poderes dentro das suas respectivas órbitas ${ }^{37}$. É a defesa da Constituição por via direta. Isso se dá, em direito brasileiro, no caso do art. $8 .^{\circ}$ da Constituição, que confere ao Procurador Geral da República legitimidade para propor, perante o Supremo Tribunal Federal, ação declaratória de inconstitucionalidade do ato que ofende os princípios enunciados no art. 7, VII, a saber, a forma republicana federativa, independência e harmonia dos poderes, a temporariedade das funções eletivas, a proibição de reeleição

36. Felipe Tena Ramirez, Derecho Constitucional Mexicano, p. 489.

37. Felipe Tena Ramirez, op. cit., p. 490. 
de governadores e prefeitos para o período imediato, a autonomia municipal, a prestação de contas da administração e as garantias do. Poder Judiciário ${ }^{38}$. "A função do Supremo não é decidir a inconstitucionalidade em tese, mas sim julgar um ato em hipótese, oriundo, de uma situação, que pode autorizar a intervenção federal. $O$ que distingue o sistema comum, inspirado na tradição do direito americano, do sistema especial, criado pela Lei n. 2.271, é, na verdade, o conteúdo da declaração. De acôrdo com o primeiro, quando o ato legislativo ou executivo ofende o direito de qualquer pessoa (física ou jurídica, privada ou direito público), recorre-se ao poder judiciário, que apreciará a questão da inconstitucionalidade como fundamento da ação ou da exceção, nunca como objeto principal do processo. De acôrdo com o segundo, o ato tem por pressuposto a violação de um (ou mais de um) dos princípios enunciados no art. $7 .^{\circ}$, VII, da Constituição Federal. No primeiro caso exerce o Tribunal a função de tutela do direito ameaçado ou lesado; no segundo, de árbitro da legitimidade de um ato, que interessa à estrutura do Estado. A sentença, no primeiro caso, é exaustiva; no segundo, não, pois a decretação de inconstitucionalidade é um prius, do qual a intervenção é o posterius. A função que o Supremo Tribunal exerce, na apreciação dos princípios fundamentais acima referidos, não é de caráter administrativo, nem legislativo; é tìpicamente jurisdicional. Trata-se, porém, de jurisdição constitucional, porque seu objeto não é resolver relações jurídicas de direito privado ou de direito público, mas compor conflito de normas do Estado, que transcendem os limites de suas atribuições. O que dá lugar à provocação do Supremo é, portanto, a existência de um litígio constitucional, proposto pelo Procurador em ação direta ${ }^{39}$.

38. Alfredo Buzaid, Da Ação Direta, p. 96 e segs..

39. Alfredo Buzaid, Da Ação Direta, p. 111 e segs.. 
11. Todavia, não é nosso propósito estudar os vários sistemas conhecidos de contrôle da constitucionalidade das leis e designadamente da defesa direta da Constituição. Intentamos analisar dois institutos que constituem expressões culminantes de garantias constitucionais e que guardam, em relação aos países onde foram criados e estão em vigor, um colorido típico, representando cada qual uma espécie do gênero comum. Referímo-nos ao amparo ${ }^{40}$ mexicano e ao mandado de segurança brasileiro, que se distinguem de outras formas atípicas de defesa constitucional. O ensaio sôbre êsses institutos vai assinalar, à luz de confrontos e contrastes, a função paralela que exercem no direito americano. $\mathrm{O}$ seu merecimento fundamental não consiste só em garantir direitos individuais, mas em conceder tutela por via constitucional. Qualquer outra espécie de proteção conferida por lei ordinária poderia desaparecer ou ser diminuída ao fluxo das deliberações do Congresso, sujeito às vicissitudes das maiorias eventuais. Conferir garantias constitucionais significa prover os direitos de remédios que correspondem à sua grandeza, à sua dignidade e à sua importância.

40. Reina dúvida sôbre a origem e a significação da palavra; se provém de imparare, tem o sentido de apossar-se, que evoluiu para exprimir a proteção daquilo de que estamos na posse. Êste é aliás um dos sentidos em português e em espanhol (NASCENTES, Dicionário Etimológico da Língua Portuguêsa, p. 27) e é lembrado por EchaNove TRUjILlo, servindo para designar outrora, em Yucatan, certo tipo de "juicios de posesion" (El Juicio de Amparo Mexicano, em Revista de la Facultad de Derecho de Mexico, 1951, I, p. 102). Nunes, Gramática Hisiórica, p. 60, deriva-o de anteparare; neste sentido MAURo CAPPELLETTI, Amparo em Enciclopedia del Diritto, II, p. 329. Para MoRAEs, parece derivar-se da preposição alemã empor (Dicionário da Língua Portuguêsa. Lisboa, 1813, I, p. 126). 


\section{Capítulo III}

\section{0 amparo mexicano.}

12. Conceito de amparo. 13. Entusiastas e críticos do instituto. Evolução da idéia. 14. Origem do instituto. 15. A Constituição de Yucatan de 1840. Antecedentes: o processo foral de Aragão. 16. Acta de Reforma de $184 \%$. $A$ Constituição de 185\%. 17. Idéias capitais sôbre que assenta o amparo. 18. Suas peculiaridades: restabelecimento do "statu quo ante"; e admissibilidade contra a lei. Natureza do prejuízo atual. 19. Sentença de amparo. Seus limites. Coisa julgada material. Jurisprudência obrigatória.

12. O amparo, ou melhor, o juicio de amparo é, na definição de IGNácio BurgoA, um meio de constitucionalidade (gênero próximo), exercitado por órgãos jurisdicionais (diferença específica, primeiro caráter), por via de ação (idem, segundo caráter), que tende a proteger o queixoso ou agravado em particular (idem, terceiro caráter), nos casos a que se refere o art. 103 da Constituição ${ }^{41}$. Embora haja várias outras definições ${ }^{42}$, o concento emitido pelo ilustre autor serve de excelente ponto de partida para a análise do instituto. O amparo é, com efeito, uma ação ajuizada pelo particular, na qual pleiteia perante a justiça a proteção contra ato de autoridade eivado de inconstitucionalidade. Èle reune em si, como observaram Calamandrei e Cappelletti, para a garantia da

41. Ignacio Burg0A, El Juicio de Amparo, 3a. ed., p. 172.

42. Cf. Rodolfo Reyes, La Defensa Constitucional, p. 33; Ramirez, Derecho Constitucional Mexicano, p. 493; LARrañagA e DE Pina, Instituciones de Derecho Procesal Civil, 2a. ed., p. 538; MORENo CoRA, Juicio de Amparo, p. 49; Trueba URBina, Nueva Legislación de Amparo, 4a. ed., p. 31 e seg.; Zamudio, op. cit., p. 111; VALlarTa, El Juicio de Amparo y el Writ of Habeas Corpus, 1881, p. 39. 
liberdade do cidadão, as funções que, na ordem jurídica italiana, estão confiadas a três institutos diferentes: o recurso de cassação, o recurso ao Conselho de Estado e o recurso à Côrte Constitucional ${ }^{43}$.

13. Os escritores exaltam, com justificada razão, as excelências do instituto, considerando-o a expressão mais característica do gênio jurídico e político mexicano ${ }^{44}$. Mas se contou com entusiastas ardorosos, teve também críticos severos; êstes se preocuparam com os abusos cometidos em seu nome, crendo que, a pretexto de tutelar o indivíduo no gôzo de garantias constitucionais, se atentava contra as instituições, ameaçadas pelo germe de um elemento anárquico; aquêles, ao contrário, vindicavam em favor do novo instituto o mérito de ser uma garantia positiva dos direitos do homem, que lhes não podiam seqüestrar nem as leis, nem os governos; instituto êsse sem similar, não o possuindo os países mais adiantados na cultura, como a França, e a Alemanha, nem os que se orgulhavam de ser mais livres, como a Inglaterra e os Estados Unidos ${ }^{45}$. A sua evolução secular é marcada por sucessivas conquistas na proteção dos direitos do homem, que sempre foi cultivada por um povo que madrugou para a maturidade política, já pelo bafejo da civilização que penetrou profundamente na sua consciência juridica, dando-lhe uma nítida idéia de sua independência democrática, já pelas comoções intestinas que foram apurando a sua sensibilidade ao ponto de não permitir que as ilegalidades da autoridade pública aniqüilassem os direitos

43. Calamandrei, Processo e Democracia, p. 14; Cappelletti, Amparo, cit., p. 329. Para LARRaÑAGA e DE PINA, Instituciones, cit., p. 540 e seg., as semelhanças entre o amparo mexicano e a cassação francesa, são mais aparentes que reais, podendo-se afirmar que os dois institutos coexistem sem incompatibilidades. Sôbre a tríplice função do amparo, ver ZAMUdio, op. cit., p. 128 e segs.

44. LaRrañaga e De Pina, Instituciones, p. 537; Rabasa, El Juicio Constitucional, p. 300 .

45. Vallarta, El Juicio de Amparo, p. 2. 
individuais sempre proclamados pelos povos civilizados, mas raras vêzes assegurados com tanto rigor como no México. A sua fisionomia foi mudando ao longo dos tempos e apesar de constituir hoje em dia uma figura modelar de proteção jurídica, ainda assim não satisfaz plenamente os mais exigentes, que lhe querem dilatar o campo de aplicação ${ }^{46}$.

14. O estudo da origem do amparo suscitou viva controvérsia entre os autores mexicanos que, ocupando-se com o tema erudita e profundamente, procederam a largas investigações históricas ${ }^{47}$. Nosso intento é traçar o seu perfil em rápido bosquejo, sem, na verdade, tomar posição em face do problema. A notícia acerca da origem e evolução do amparo tem por objetivo ressaltar a prioridade do pensamento jurídico mexicano sôbre o dos demais países; além disso, o desenvolvimento das idéias jusnaturalistas e de federalismo, difundidas pelos norte-americanos, permitiu muito cedo o florescimento do instituto com o colorido peculiar que recebeu, o qual, se é até certo ponto semelhante aos writs, destinados à proteção dos direitos individuais, conseguiu ser superior ao modêlo em que se inspirou ${ }^{48}$. A constituição americana foi difundida lentamente, não só porque escrita em idioma inglês, como ainda em conseqüência da exígua literatura jurídica daquêle tempo. O que concorreu para divulgá-la no México foi a tradução para o castelhano da obra de Alexis

46. Felipe Tena Ramirez, op. cit., p. 512 e segs.

47. Cf. Burgoa, El Juicio de Amparo, p. 50 e segs.; Vallarta, op. cit., p. 22 e segs.; RABASA, El Derecho Anglo-Americano, p. 633 e segs.; Urbina, op. cit., p. 10 e segs.; Armando Herrerias Tellerias, Origenes Externas del Juicio de Amparo, em Revista de la Faculdad de Derecho de Mexico, V, n.o 19, p. 35 e segs.; Echanove Trujillo, El Juicio de Amparo Mexicano, em Revista, cit., p. 94 e segs.; REYS, op. cit., p. 34 e segs.; RAMIREZ, op. cit., p. 493 e segs.; NiCETo ALCALÁ Zamora, y Castillo, Ensayos, p. 524 e segs.; idem, Proceso, Auto composición y Auto defensa, p. 206 e segs.; Gomes, La Ley, XX, p. 249 e segs.; BIElsA, Estudios de Derecho Publico, III, p. 398 e seg.

48. URBINA, op. cit., p. 3. 
DE Tocoueville, La Democratie en Amérique, chegada ao México em 1837 e vendida, segundo a informação de TruJillo "en el cajón" de libros de Hipolito Segun, Portal de Mercadores" ${ }^{49}$, cuja leitura foi decisiva para mostrar aos juristas o funcionamento do juízo constitucional dos Estados Unidos. O referido escritor assinala que "foi, pois, o livro de Tocoueville, traduzido, o que veio a expor ao mundo de língua castelhana, com penetração admirável e estilo ameno, as concepções e procedimentos judiciais dos nossos vizinhos norte-americanos" 50 .

15. Sustenta Urbina que a intuição de um juicio de amparo parece ter surgido na constituição mexicana de 1824, ao atribuir à Côrte Suprema a competência para conhecer de violação a preceitos da Lei Magna, além de estabelecer a tutela jurisdicional dos direitos dos indivíduos ${ }^{51}$. Rabasa pensa, ao contrário, que a Constituição de 1823 não declarou a supremacia dos seus preceitos sôbre as demais leis, nem continha um capítulo enumerativo de garantias individuais, possivelmente porque os legisladores constituintes, nessa época, não estavam ainda inteirados da instituição que se havia implantado nos Estados Unidos ${ }^{52}$. Para Ramirez, foi a Constituição centralista de 1836 que pela primeira vez se ocupou com o tema

49. TrujILlo, op. cit. Rev. cit., p. 95.

50. Trujilio, op. cit., p. 96.

51. URBINA, op. cit., p. 10.

52. RABASA, El Derecho Anglo-americano, p. 633. Não procede, na realidade, a opinião de URBINA, que vê no art. 137, V. 6 da Constituição de 1823 o antecedente remoto do juízo de amparo; como observou Echanove TruJillo, tal preceito equivalia a lançar as bases do juízo constitucional; mas os legisladores mexicanos não se deram conta cabal do seu alcance, tendo sido inserido como ato de mera cópia do que, em têrmos iguais, existia na norte-americana de 1789 . Não só se desconhecia então, fora dos Estados Unidos, o desenvolvimento que sua jurisprudência já havia dado ao juízo constitucional, como também, pelo que toca ao México, êsse estranho artigo ia permanecer por dczesseis anos absolutamente inoperante (Revista, cit., 1951, I, p. 92 e segs.). 
e pretendeu resolvê-lo mediante a instituição de um órgão político, chamado Supremo Poder Conservador, composto de cinco membros eleitos seletivamente pelas Juntas Departamentais, Câmara de Deputados e Senado. A sua função consistia em declarar a nulidade dos atos contrários à Constituição, de um dos três poderes, por solicitação de qualquer dos dois outros. Éste sistema malogrou, não porque apresentasse defeitos, mas precisamente por disfunção. Durante cinco anos o Poder Moderador interveio em quatro casos e em nenhum dêles em defesa da Constituição ${ }^{53}$.

Ao que parece, todos estão de acôrdo em que o antecedente próximo do amparo ${ }^{54}$ está no projeto de Consti-

53. RAMIREZ, op. cit., p. 493.

54. O fenômeno histórico mais importante da Espanha e que mantém certa afinidade com o amparo é o privilégio geral ou processo foral de Aragão, de onde derivaram garantias individuais que foram, com o tempo, consagradas na Constituição aragonesa. Entre elas figuram o salvo-conduto às testemunhas para deporem em causas criminais, a obrigação de os juízes darem os seus votos públicos, a anulação do processo por êrro ou omissão de formalidade legal e o chamado processo de manifestação. A conquista destas franquias foi o epílogo da luta entre os municípios e côrtes gerais de um lado e do outro, o poder real, a fim de contê-lo nas usurpações das liberdades. O monarca não recebia a investidura por direito divino, mas da vontade popular, transmitida em fórmula que se tornou célebre: "Nós, que valemos tanto como vós, e podemos mais do que vós, vos fazemos nosso Rei e Senhor, com a condição que nos guardareis nossas liberdades; senão, não." (VIARDot, História das Instituições, Lisboa, 1884, p. 71. D. JUAN Francisco LA RIPA, em sua obra Segunda ilustración a los quatro procesos forales do Aragon, 1772, assim descreve a função do grão-juiz, que, acompanhado de seus acessores, julgava entre o Rei e o povo: "Quando los aragoneses se eligieron Rey, le dieron ya las Leyes, bajo las que los habia de gobernar: $\mathrm{Y}$ por si sucediese venir contra ellas, de forma que resultasen agravios a los Vassalos, o para quando entre estos se originasen algunas discordias, eligieron en Juez medio entre ellos, y su Rey, a quien después distinguieron con el nombre de Justicia de Aragón, para que oyese las quexas de los que se decían oprimidos por la transgresión de sus Leyes, y quitar las violencias, que se les irrogasen contra sus Derechos. No le dieron al Justicia la facultad legislativa; ántes se la 
tuição elaborado em 1840 por Manuel Crescêncio Rejón para o Estado de Yucatan. Visivelmente inspirado no sistema norte-americano, êle insere um plano de garantias constitucionais e confia a sua proteção ao Poder Judiciário. $\mathrm{O}$ art. 53 do referido Projeto estabelecia: "Corresponde a êste tribunal reunido (Côrte Suprema de Justicia del Estado): "1. ${ }^{\circ}$ - Amparar en el goce de sus derechos a los que le pidan su protección contra las leyes y decretos de la Legislatura que sean contrarios a la Constitución;

reservaron para el Rey, y para el Reyno. Hicieronlo solo zelador fiel de las Leyes, con cargo de que velase sobre las opresiones contra todos, de forma, que ni la Soberania pudiese jamás irrogarles ningun aggravio.. " (Cf. REYs, La Defensa Constitucional, p. 327; VALlaRTa, op. cit., p. 431). O enunciado que acaba de ser transcrito mostra que os aragoneses tiveram uma clara compreensão de que os poderes deviam ser divididos, ficando reservada a função legislativa ao Rei e ao Reino, para que êste, por seus representantes, elaborasse as normas a que todos deviam ficar sujeitos; o próprio Rei só podia governar conforme , as leis que fôssem editadas; mas o que há de grandioso é que entre - Rei, que concentra o que hoje chamamos a função executiva, e os direitos dos vassalos que fôssem agravados por ato do poder real, medeia um magistrado, denominado a Justicia Mayor, a quem tocava a tarefa de ouvir as queixas dos que se diziam prejudicados por transgressão de suas leis e obstar as violências praticadas contra seus direitos. Fiel zelador das leis, contra êle não prevalecia nem mesmo o poder soberano do Rei. Confiava-se assim à suprema magistratura a competência para dirimir os litígios oriundos de ofensa aos direitos individuais, sobrepondo-se à Justicia de Aragon até à autoridade da coroa. No n.o 9 da obra já referida, diz o ilustre autor: "Los nombrados en el Paragrafo antecedente (Los Lugartenientes de la Justicia, llamados Insaculados porque eran sorteados por los Disputados del Reyno) eran las Personas principales, que formaban aquel grande Tribunal, que despachaba sus amparos en defensa del Rey, de las Leyes $e$ de los Regnicolas"... "No los quitaba, no al habiente derecho; no hacía mas, que ponerlos en seguro." (REYs, op. cit., p. 327). Aparece aí a palavra amparo, concedido a favor do Rei e dos reinícolas e, destinado a pôr em seguro (ponerlos en seguro) os que fôssem agravados por opressão, fôrça, violência, ou por atos praticados contra o fuero. Estas duas palavras tiveram uma seducão mágica. A primeira serviu para designar o instituto mexicano; a segunda, o instituto brasileiro. Aquêle se chama juicio de amparo; êste, mandado de segurança. 
o contra las providencias del Gobierno e Ejecutivo reunido, cuando en ellas se hubiesen infringido el Código Fundamental o las leyes, limitándose en ambos casos a reparar el agravio en la parte en que éstas o la Constitución hubiesen sido violadas." E o art. 63: "los jueces de primera instancia ampararán en el goce de los derechos garantizados (los individuales que antes enumera) a los que les pidan su protección contra cualesquiera funcionarios que no correspondan al orden judicial, decidiendo breve y sumariamente las cuestiones que se susciten sobre los asuntos indicados" 55 .

Embora o projeto contivesse uma declaração de garantias constitucionais, o certo é que, referindo-se a um Estado e não a todo o país, só podia atribuir ao Judiciário local a competência para proteger o indivíduo contra as leis e decretos da legislatura, avessos à Constituição, ou atos do Executivo, infringentes do Código Fundamental e das leis. Êsse fato, na história constitucional mexicana, assegurou a REJón o mérito de ser o precursor do amparo ${ }^{56}$. Conta Rabasa que, no Congresso Constituinte de

55. Cf. URBina, op. cit., p. 14 e seg.

56. RABASA, El Derecho Anglo-americano, p. 634; URBINA, op. cit., p. 14. A exposição de motivos do projeto da Constituição de Yucatan é rica de considerações acêrca do fortalecimento do judiciário, que é dos três poderes o mais tranqüilo e apoiado na autoridade moral que deve dar-lhe a justiça de suas decisões; considera-o suficiente para anular as providências inconstitucionais do Congresso e ilegalidades do Executivo nas ofensas feitas aos direitos políticos e civis dos habitantes do Estado. Dotado da faculdade de proteger as garantias constitucionais, enobrece sua função, porque elas constituem o objeto essencial de tôda a ordem política sob a salvaguarda daquele que, responsável por seus atos, saiba custodiar o sagrado depósito que se confia à sua fidelidade e vigilância (TruJilıo, op. cit., p. 99 e seg.). Mas ao prudente espírito de REJón não passaria despercebida a indagação relativa ao perigo da omnipotência judicial. Se os juízes fiscalizam os atos dos demais poderes, quem fiscaliza os juízes? Qui custodet custodes? A solução, deu-a no art. 9.0 da Constituição de Yucatan: "Dos atentados cometidos pelos juízes contra os citados direitos (do 
1842, reunido para promulgar a nova Constituição Nacional, a comissão encarregada de elaborar o novo projeto se dividiu em duas tendências das quais a da minoria, integrada pelos deputados MuÑoz Ledo, Espinoza dE LOS Monteros e o jovem e abalizado advogado Don Mariano OTERo, propôs uma enumeração de garantias constitucionais que deveriam consignar-se na Lei Fundamental da Nação, confiando aos Tribunais Federais a sua tutela. Tal projeto não vingou ${ }^{57}$.

O tema estava, porém, na ordem do dia. No programa da maioria dos deputados do Distrito Federal, de 29 de novembro de 1846, subscrito por REJón, declarou-se: "Ahora bien: para hacer eficaz esta declaración será a propósito prevenir en la Constitución: 1. ${ }^{\circ}$ Que los jueces de primera instancia amparen el goce de los citados derechos a los que les pidan su protección contra cualesquiera funcionarios que no correspondan al orden judicial decidiendo breve y sumariamente las cuestiones que se susciten sobre los asuntos indicados. 2..$^{\circ}$ Que de la injusta negativa de los jueces a tratar el referido amparo, así como de los atentados cometidos por ellos contra los mencionados derechos, conozcan sus respectivos superiores con la misma preferencia remediando desde luego el mal que se les reclame y enjuiciando inmediatamente al juez omiso o que conculque las citadas garantias; y $3 .^{\circ}$ Que los fallos de los jueces sobre el amparo de que se trata, sean puntualmente obedecidos y acatados por todos los funcionarios públicos de cualquiera clase o condición que sean so pena de privación de empleo y sin perjuicio de las otras que demande en el caso de desobediencia o resistencia a cumplirlo según la lei lo disponga" 58 .

homem) conhecerão seus respectivos superiores." A caraterística do sistema de REJón foi conferir uma ação de amparo e não um recurso; e foi precisamente aí que sobrepondo-se ao modêlo norte-americano, inovou criando um sistema original (Trujillo, op. cit., p. 100 e seg.). 
16. Surge o juicio de amparo na Acta de Reformas; de 1847 com a seguinte justificação: "Los frecuentes ataques de los poderes de los Estados y Federación a los particulares, hacen urgente que, al restablecerse la Federación, se dé a aquéllos una garantia personal; esta garantía sólo puede encontrarse en el Poder Judicial, protector nato de los derechos de los particulares y por esta razón el solo conveniente... en Norteamérica este poder salvador provino de la Constitución y ha producido los mejores efectos. Allí el juez tiene que sujetar sus fallos, antes que todo a la Constitución y de aquí resulta que cuando la encuentra en pugna con la ley secundaria, aplica aquélla y no ésta, de modo que sin hacerse superior a la ley ni ponerse en oposición contra el Poder Legislativo, ni derogar sus disposiciones, en cada caso en que ella devía herir, la hace impotente. Una institución semejante es del todo necesaria entre nosotros... también se necesita extender un poco más la acción del Poder Judicial de la Unión, muy imperfectamente organizada en la Constitución Federal y sobre todo, elevar la condición y asegurar la independencia de un tribunal llamado a representar en el campo político un papel tan importante como el del Supremo Poder Judicial" ${ }^{59}$. O art. 25 declara textualmente: "Los tribunales de la Federación ampararán a cualquier habitante de la República en el ejercicio y conservación de los derechos que les conceden esta Constitución y las leyes constitucionales, contra todo ataque de los Poderes Legislativo y Ejecutivo, ya sea de la Federación, ya del Estado, limitándose dichos tribunales a impartir su protección en el caso particular sobre el que verse el proceso, sin hacer ninguna declaración general respecto de la ley o del acto que lo motivase" ${ }^{60}$. Esta fórmula sintética, apta a sagrar a idéia fundamental do instituto, seus pressupostos e o campo de sua aplicação,

59. URBINA, op. cit., p. 17.

60. URBINA, op. cit., p. 18. 
foi elaborada por OTERo, a quem a história conferiu o título de "criador do juicio de amparo". Entre os méritos do ilustre legislador se inclui o de haver sugerido três idéias fundamentais: a) - fazer da queixa contra a infração um juízo especial e não um recurso; b) - restringir só aos tribunais federais a competência para conhecê-la; c) e proibir qualquer declaração geral sôbre a lei ou atos violadores da lei ${ }^{61}$.

Dez anos depois a aspiração se convertia numa esplêndida realidade, incorporando-se na Constituição de 1857 a fórmula elaborada por OTERo, que nunca mais se afastou do sistema mexicano; ao contrário, foi sendo aperfeiçoada, em sua evolução, para abranger, em seu alcance, não apenas a ofensa produzida pelo executivo e legislativo, mas também por autoridades judiciárias. Estava criado, pois, definitivamente, o juízo constitucional de amparo, instituto que tornou inolvidáveis os nomes de ReJón e OtERo e revelou o espírito criador do direito mexicano, apresentando ao mundo um remédio jurídico idôneo à tutela jurisdicional dos direitos subjetivos ofendidos por ato de qualquer poder. Daí por diante, numa continuidade nunca interrompida, a cultura jurídica mexicana preservou sempre o instituto que conta mais de um século. Ėle representa o triunfo do sistema federativo e o primado da constituição rígida, servindo para manter, como observou Emílio Rabasa, cada poder nos limites de sua competência em relação às pessoas que podem sofrer arbitrariedade, em relação aos poderes entre si, definidas as suas atribuições; e em relação à forma de govêrno, de modo a assegurar ação tanto do poder federal quanto do estadual ${ }^{62}$.

As reformas constitucionais posteriores a 1917 foram corrigindo, especialmente em relação ao processo, algumas deficiências e o texto da Constituição atual prescreve:

61. Rabasa, op. cit., p. 635 .

62. RABASA, op. cit., p. 636 e seg.. 
"Los tribunales de la Federación resolverán toda controversia que se suscite: I - Por leyes o actos de la autoridad que viole las garantías individuales. II — Por leyes o actos de la autoridad federal que vulneren o restrinjan la soberanía de los Estados. III - Por leyes o actos de las autoridades de éstos que invadan la esfera de la autoridad federal" ${ }^{63}$.

17. Reconhecem os autores que são três as idéias capitais sôbre que assenta o amparo, oriundas da fórmula de OTERo e conservadas até à Constituição vigente: a) o juicio há de ser formulado pela parte agravada pelo ato inconstitucional; b) a parte há de ser pessoa física, ou jurídica, mas sempre particular; c) limitar-se-á a sentença a resolver o caso particular, sem declaração geral acêrca da lei ou do ato que motivou a ofensa ${ }^{64}$. Estas idéias, observou Ramirez, plasma o instituto de acentuado individualismo, em tal grau que se o estudarmos sem preconceitos, haveremos de convir em que não se trata, na realidade, de um sistema de defesa direta da Constituição, senão de defesa primordial do indivíduo em face do Estado, que se resolve em defesa secundária e eventual da

63. URBinA, op. cit., p. 23.

64. Lei de Amparo, art. 8.0; Urbina, op. cit., p. 106; RabaSA, op. cit., p. 635 . O emprêgo da expressão juicio de amparo (Const., art. 27, XIV; Lei Orgânica, art. 1.0) suscitou controvérsia sôbre a natureza do instituto, prevalecendo a doutrina que não se trata pròpriamente de um juicio, nem de um recurso, mas, na realidade, de um processo (URBINA, op. cit., p. 29). Êste mesmo autor sustenta ainda que o amparo pode revestir as duas formas: a de recurso, quando versa sôbre a garantia da exata aplicação da lei (violação do art. 14 da Constituição); e juicio, quando tem por objeto a resolução de violação de garantias constitucionais não indicadas no referido art. 14 . Do ponto de vista formal será um juicio, ainda que, tècnicamente falando, um processo. Para BurgoA é um verdadeiro juicio ou ação sui generis, distinta e independente do processo em que surge o ato reclamado ( $E l$ Juicio de Amparo, p. 175). ZAMUdio considera-o uma ação, a que corresponde por parte do Estado uma prestação jurisdicional (op. cit, p. 108 e segs.). 
Constituição. Com efeito, das duas partes em que dividimos as Constituições do tipo mexicano, uma erige como limitações às autoridades certos direitos da pessoa, enquanto a outra organiza os poderes públicos entre si. Como todo ordenamento jurídico, ambas regulam as relações dos poderes com os indivíduos - a parte dogmática; e dos poderes entre si — a parte orgânica. O genuinamente constitucional é a parte orgânica; suprimam-se de uma Constituição os preceitos que criam e organizam os poderes públicos dotando-os de competência, e não haverá Constituição: em compensação hả numerosas Constituções que, sem deixar de merecer tal nome, carecem de enumeração dos direitos públicos da pessoa, chamados entre nós garantias constitucionais. E é que, se não se incluem êsses direitos em algumas constituições, é em virtude da ideologia individualista das mesmas, que de certo não é aceita unânimemente e em igual medida pelas demais. Das duas partes que distinguimos numa Constituição como a mexicana a mais digna de ser defendida, do ponto de vista constitucional, é a parte orgânica, que é substancialmente constitucional. A defesa da outra tem suma importância, porém não do ponto de vista da Constituição senão do indivíduo. Por isso o autêntico contrôle da constitucionalidade é o que tem por objeto manter os poderes dentro das suas competências respectivas, impedindo recíprocas interferências. Não é pròpriamente contrôle da constitucionalidade aquêle que só cuida de evitar as invasões dos poderes na esfera dos direitos públicos da pessoa. Sem dúvida as invasões dêste gênero são formalmente violações à Constituição, porque os direitos infringidos figuram nela; porém não constituem violações do essencialmente constitucional. À luz dêstes princípios, continua Ramirez, vejamos se o amparo realiza ou não verdadeiro contrôle da constitucionalidade. Segundo se infere do art. 103, os objetivos do juízo consistem em impedir as violações das garantias individuais por parte de qualquer autoridade, assim como as invasões 
da justiça federal na local e vice-versa. Dêstes, o primeiro realiza integralmente a defesa da parte dogmática da Constituição; nada tem, pois, de contrôle da constitucionalidade em sentido estrito; o segundo se ocupa, na aparência, em salvaguardar algo que é tìpicamente constitucional, como a conservação, dentro das suas esferas respectivas, das jurisdições federais e locais. Mas, para que se alcance a proteção é preciso, conforme o inciso I do art. 107, que a invasão de competências repercuta em prejuízo de um indivíduo e que o agravado reclame a proteção; o que quer dizer que, ainda no caso de custódia a uma posição orgânica da Constituição, fica a defesa subordinada à condição de que lese um indivíduo e de que êste queira que se repare em sua pessoa um agravo cometido à organização dos poderes. Não importa a lesão em si à Lei Suprema senão só enquanto se traduz em dano a um indivíduo, que é o único que parece interessar à Constituição. Reparado o dano causado ao queixoso, fica a violação geral impune em si mesma e em relação aos indivíduos que a não reclamaram, porque a sentença não vale senão para o caso concreto, não podendo fazer declaraçôes gerais acerca da inconstitucionalidade do ato violador. Eis aí como as idéias de OTERo, ampliadas pela Constituição de 56 aos casos de invasão de atribuições, tornaram impossivel o contrôle completo e autêntico da constitucionalidade ${ }^{65}$.

65. RAMIREZ, op. cit., p. 512 e segs. E conclui êste insigne autor: os três incisos do art. 103 que fundamentam a procedência do amparo estão ao serviço do indivíduo e não ao serviço direto da Constituição; não há razão, pois, para estabelecer distinção entre êles. 0 primeiro alude a violações de garantias constitucionais; o segundo, a violações da jurisdição local pela federal e a terceira, à invasão da jurisdição federal, pela local. Como êstes dois últimos casos implicam falta de competência, traduzem-se a final em violação da garantia individual que consagra o art. 16, consistente em que ninguém pode ser molestado senão em virtude, entre outros requisitos, de mandado escrito de autoridade competente. Para que invocar, pois, os incisos II e III, se para alcançar o amparo basta o número I? Assim o amparo reivindicou seus 
18. Ação tendente a instaurar um litígio constitucional, o amparo tem algumas peculiaridades que o distinguem substancialmente das demais figuras de tutela jurídica. Uma delas está na suspensão do ato impugnado, de modo a impedir que a violação altere o statu quo ante; tal procedimento restaura de pronto o gôzo do direito ofendido, além de evitar a consumação de prejuízos, cuja reparação seria meramente pecuniária ${ }^{66}$. Embora a função da suspensão seja acautelatória ${ }^{67}$, ela se vincula à índole do amparo que, como remédio preordenado à tutela de direitos violados por ato inconstitucional da autoridade pública, estava a exigir uma reação enérgica e capaz de eliminar, de imediato, o estado de fato, contrário ao direito. Os direitos tutelados pelo amparo não podem ser equiparados aos que se fundam em crédito ou obrigação; enquanto, em relação a êstes, o autor tem o duplo ônus de alegá-los e prová-los, a fim de obter uma sentença favorável, aquêles valem por si, em virtude de sua meridiana clareza e evidência; ou, em outras palavras, propõem-se em juízo os direitos de crédito; os direitos constitucionais impõem-se por si ${ }^{68}$.

Outra caraterística ẻ a da admissibilidade do amparo contra a lei. Ramirez sustenta que a questão da oportunidade não é, no fundo, senão a da titularidade. Só o particular lesado é titular da ação de amparo. Portanto, desde que (ou até que) se produza o dano, é possível localizar o agravado (titularidade). Lozano (Derechos del Hombre, pg. 439 e seg.) e Vallarta (Notas, ed. 1897,

fôros individualistas, $\Theta$ a jurisprudência e os litigantes se habituaram a entender e sentir a instituição através do indivíduo, relegando ao olvido e desuso os dois últimos incisos do art. 103 (op. cit., p. 515).

66. URBINA, op. eit., p. 33.

67. Larrañaga e De Pina, op. cit., p. 546.

68. LaRrañaga e DE PiNA, op. cit., p. 547, dizem que a suspensão pode ser decretada de ofício ou por solicitação da parte; pode ser provisória ou definitiva; a primeira é concedida, enquanto se resolve o incidente; a segunda até que se pronuncie a sentença de amparo. 
IV, pg. 270 e segs.), sustentaram que, enquanto não se executa a lei, deve ela ser tida como morta. Não ofende, nem causa prejuízo. Por isso, não se ampara contra a lei em tese. Rabasa (El juicio Constitucional, pg. 240 e segs.) impugna a lição citada, perguntando, quando se diz cometida pela lei a violação nos casos de lesão de direito individual? A resposta se impõe necessàriamente: desde o momento em que pela promulgação o ato legislativo adquire fôrça de determinação obrigatória que deve cumprir-se. A lei de amparo de 1919 acolheu a tese de Lozano e Vallarta; a de 1953 admitiu a possibilidade de atacar os vícios de inconstitucionalidade de uma lei ainda antes de sua aplicação. A reforma de 1951 erigiu o elemento "prejuízo" como integrante da titularidade da ação de amparo. Determinar o prejuízo atual que produz a lei antes de sua execução é o que interessa fixar para a procedência do amparo contra leis ainda não aplicadas, mas aplicáveis. Êste prejuízo consiste em que uma situação que era legal antes da lei se converte em ilegal a partir de sua vigência. É evidente o prejuízo que se causa a um particular pelo só fato de pôr fora da lei uma atividade, uma abstenção, uma atitude, um bem em suma dêsse particular que na véspera estava dentro da lei. Tudo isto, independentemente da futura destruição de tal bem, mediante a execução correta da lei. Dêste modo o amparo contra a lei é admissível quando se situa em um indivíduo o prejuízo atual consistente na mudança produzida pela lei, do legal ao ilegal no status dêsse indivíduo. O prejuízo atual é também real, porque a situação ilegal em que é posto $o$ indivíduo condiciona inevitàvelmente a execução futura, que é por si mesmo um prejuízo perfeitamente real verificável ${ }^{69}$.

19. A sentença de amparo deve limitar-se a declarar o direito invocado pela parte, pessoa física ou jurídica, no caso concreto, sem fazer declaração geral acêrca da

69. RAMiREZ, op. cit., p. 531 e segs. 
lei ou do ato que a motivou ${ }^{70}$. A sentença tem caráter positivo ou negativo; a que concede o amparo, esclareceURBINA, tem por objeto restituir o agravado no pleno gôzo de garantia individual violada, restituindo as coisas no estado em que se achavam antes da violação, quando o ato reclamado fôr de caráter positivo; quando negativo, o efeito do amparo será obrigar a autoridade responsável a que obre no sentido de respeitar a garantia de que se trata e a cumprir, por sua parte, o que a mesma garantia exige ${ }^{71}$. A sentença produz coisa julgada material, nos limites da decisão, tornando indiscutivel o ponto questionado ${ }^{72}$.

Em dois preceitos, um constitucional de caráter genérico (art. 107, XIII) e outro especial da Lei de Amparo (art. 193) se estabeleceu que a jurisprudência da Suprema Côrte de Justiça, firmada em plenário sôbre a interpretação da Constituição e leis federais ou tratados celebrados: com potências estrangeiras é obrigatória, assim para ela como para as turmas que a compõem, os Tribunais dos Estados e demais juízes da nação, que por isso mesmo não podem esquivar-se à sua observância. Elevando a jurisprudência à fonte de direito, preocupou-se o legislador mexicano em conceituá-la: "Las ejecutorias de las Salas de la Suprema Corte de Justicia constituyen jurisprudencia, siempre que lo resuelto en ellas se encuentre en cinco ejecutorias no interrumpidas por otra en contrario, y que hayam sido aprobadas por lo menos por

70. Lei de Amparo, art. 76.

71. URBina, op. cit., p. 36. Lembra êste autor que, de acôrdo com a jurisprudência da Suprema Côrte, as sentenças de amparo só podem resolver sôbre a constitucionalidade ou não do ato que se impugna e nunca sôbre questões, cuja decisão caiba aos tribunais do fôro comum. Também sustenta que a sentença não pode tomar em consideração vio-lações de garantia que o interessado não fêz valer na demanda. Esta. tese vale para os amparos civis, administrativos e trabalhistas.

72. Vallarta, op. cit., p. 295 e segs.. 
cuatro Ministros." 73 As duas regras juridicas tendem a assegurar a uniformidade da jurisprudência, evitando que as declarações judiciais, designadamente as relativas à inconstitucionalidade, fiquem expostas às oscilações das maiorias eventuais, abalando a majestade dos julgamentos pela administração de diferentes justiças na aplicação de uma mesma lei, resultando dai diversidade de tratamento para os que se socorrem do amparo. Mas até que ponto essa submissão à jurisprudência é um bem ou um mal e em que medida obriga a magistrado a seguí-la, - é um problema de ontológico que envolve duas exigências distintas: a do juiz que não quer votar contra a sua consciência; e da segurança coletiva, que precisa ser resguardada pela linha uniforme de decisões concordes. O juiz está obrigado a obedecer à lei, mas desde que a jurisprudência foi erigida legalmente em fonte de direito, deve valer tanto uma como a outra. A diferença entre a lei e a jurisprudência está em que esta pode ser modificada pela Côrte Suprema com observância do art. 194 da Lei de Amparo, enquanto que aquela, só por outra lei ${ }^{74}$.

Eis aí, em uma síntese descritiva, o instituto do amparo, do qual procuramos ressaltar aspectos fundamentais, não só da história de sua elaboração como de sua dogmática vigente, sem outro propósito que o de assinalar os pontos de confronto e de contraste com a figura congênere do mandado de segurança adotada pelo direito constitucional brasileiro.

73. Lei de Amparo, art. 193; URBiNa, op. cit., p. 308.

74. GuILlebaldo Murillo, La Jurisprudencia Obligatoria em Problemas Juridicos de Mexico, Ed. Jus, 1953, p. 158 e seg., escreve: "Já se disse no México que a jurisprudência é obrigatória, porque se impõe como a ciência, a sabedoria, o heroismo, a santidade, a graça de Deus; mas já se observou também que se não necessita de nenhuma lei para que a ciência e a sabedoria sejam obrigatórias, já que valem por si mesmas; assim também não há necessidade de lei que declare a obrigatoriedade da jurisprudência. 
Capítulo IV

Direito Brasileiro

$\S 10^{\circ}$

Os direitos individuais na Constituição imperial e na primeira Constituição republicana.

\begin{abstract}
SumárIo: 20. Os direitos individuais na Constituição Imperial. 21. A lei n.0 221 de 20 de novembro de 1894. $O$ emprêgo do "habeas corpus" $e$ dos interditos para a proteção dos direitos pessoais. 22. Reação na doutrina e na jurisprudência. Reforma constitucional de 1926. O "habeas corpus" só protege o direito de locomoção. A consciência jurídica nacional reclama um sucedâneo do "habeas corpus".
\end{abstract}

20. A exemplo e semelhança dos povos civilizados, o Brasil inaugura o regime político do Império, inserindo, na sua primeira Constituição, solene declaração dos direitos individuais. O projeto, elaborado por ANTonio CaRlos Ribeiro de Andrada Maghado e Silva, na Assembléia Geral, continha 272 artigos ${ }^{75}$. No capítulo II do título II (art. 7 e segs.) foram consignados os direitos individuais dos brasileiros. Definindo o que seja matéria pròpriamente constitucional, prescreveu o art. 287: “É só constitucional o que diz respeito aos limites e atribuições respectivas dos poderes políticos e aos direitos políticos e individuais". A matéria constitucional não podia ser al-

75. Sôbre a origem dos projetos, seus redatores e o desenvolvimento constitucional dêsse período, ver: CESAR TRIPOLI, História do Direito Brasileiro, II, p. 166 e segs.; WaLDEMAR MARTINS FERREIRA, História do Direito Constitucional Brasileiro, p. 47 e segs.; J.P. Galvão DE Sousa, Introdução à História do Direito Político Brasileiro, p. 129 e segs.; TAvares De LYRA, Organização Política e Administrativa do Brasil, p. 49 e segs.; Odilon Araujo Grellet, Ensaio sôbre a Evolução do Direito Constitucional Brasileiro, p. 25 e segs.. 
terada pela legislação ordinária. É o que dispunha o art. 288: "Tudo o que não é constitucional pode ser alterado pelas legislaturas ordinárias, concordando dois terços e dada uma das salas" Êste projeto, de inspiração liberal, não prosperou, porque D. PEDro I dissolveu a $12 \mathrm{de}$ novembro de 1823 a Assembléia Constituinte; no dia seguinte nomeou um Conselho de Estado, composto de dez membros, atribuindo-lhe o encargo de elaborar novo projeto de constituição. Um mês depois estava concluído o trabalho, que reproduziu em grande parte o projeto anterior. A 25 de março de 1824, D. Pedro I, imperador e defensor perpétuo do Brasil, outorgou a primeira Constituição política, afirmando-se nela "a inviolabilidade dos direitos civis e políticos dos cidadãos brasileiros, que tem por base a liberdade, a segurança individual e a propriedade." (art. 179), exarados em trinta e cinco parágrafos. A inscrição dos direitos individuais, nesse primeiro documento constitucional brasileiro, traduzia as aspirações liberais, democráticas e jusnaturalistas da época ${ }^{76}$; mas, como a Constituição francesa, que lhe serviu de modêlo, tais direitos não foram dotados de ação judiciária capaz de obter a sua pronta e enérgica reparação perante os tribunais, quando ofendidos por ato ilegal do poder público ${ }^{77}$.

21. Até ao advento da República não se assinala a êste respeito nenhum progresso. A própria Constituição de 24 de fevereiro de 1891 não se avantajou de muito ao direito herdado do Império ${ }^{78}$. A primeira manifestação

76. Pimenta Bueno, Direito Público Brasileiro e Análise da Constituição do Império, n.os 534 e segs.; JOAqUIM RodRIGUES DE SousA, Análise e Comentário da Constituição Política do Império do Brasil, 1870 , II, p. 455 e segs..

77. Cf. Rui Barbosa, Comentários, cit., vol. V, p. 176; RosaH Russomano DE Mendonça Lima, Os Direitos e Garantias Individuais na História do Brasil, p. 16.

78. A Constituição brasileira de 1891 estendeu aos estrangeiros residentes no país as garantias de direitos individuais (art. 72), equi- 
clara e inequívoca aparece na Lei $n .^{\circ} 221$, de 20 de novembro de 1894, que institui uma ação especial destinada a invalidar atos ou decisões de autoridades administrativas federais, lesivos dos direitos dos indivíduos. Desta lei foi autor Rodrigo Octávio; êle mesmo narra que, em dias de setembro de 1894, Campos Sales lhe confiou uns tantos projetos de lei em andamento no Senado, de que fazia parte pedindo-lhe que os ordenasse e preparasse com urgência um plano de reorganização da Justiça Federal, bem como de seu processo. Entre os papéis figurava um projeto, da lavra de José Higino sôbre ação fundada em lesão de direitos individuais. Pôs mãos à obra e dois dias depois levou a CAmpos SALES os originais, procurando desculpar-se com a explicação de que eram apenas borrões escritos às pressas. No dia seguinte, com surpresa para Rodrigo Octávio, aquêle trabalho, sem qualquer retoque, era apresentado por Campos Sales ao Senado, que o aprovou e remeteu à Câmara dos Deputados. Nesta foi votado sem discussão. Sobe $o$ autógrafo à sanção. $O$ Presidente Floriano Peixoto deixou escoar-se o prazo. Devolvido ao Presidente do Senado, Manuel Victorino Pereira, promulga e manda publicar a lei, no dia 20 de novembro de 1894, a qual recebeu o n. ${ }^{0} 221^{79}$.

Do art. 13 desta lei merecem ser ressaltados, além do caput, os seguintes parágrafos: Art. 13. Os juízes e tribunais federais processarão e julgarão as causas que se fundarem na lesão de direitos individuais por atos ou decisão das autoridades administrativas da União." " $1 .^{0}$ - As ações desta natureza sòmente poderão ser propostas pelas pessoas ofendidas em seus direitos ou por seus representantes ou sucessores. $\S 20^{\circ}-\mathrm{A}$ autoridade ad-

parando-os para tal fim aos brasileiros, ao passo que a Constituição imperial, só assegurava aos brasileiros a inviolabilidade dos direitos civis e políticos (Carlos Maximiliano, Comentários à Constituição Brasileira, 4.a ed., vol. III, p. 27).

79. Rodrigo Octavio, Minhas Memórias dos Outros, 1a. série, p. 140 e segs.. 
ministrativa, de quem emanou a medida impugnada, será representada no processo pelo ministério público. $\& 7 .^{\circ}$ - A requerimento do autor, a autoridade administrativa que expediu o ato ou medida em questão suspenderá a sua execução, se a isso não se opuzerem razões de ordem pública. $\S 10^{\circ}$ - Os juízes e tribunais apreciarão a validade das leis e regulamentos e deixarão de aplicar aos casos ocorrentes as leis manifestamente inconstitucionais e os regulamentos manifestamente incompatíveis com as leis ou com a Constituição. $\S 110^{\circ}$ - As sentenças judiciais passarão em julgado e obrigarão as partes e a administração em relação ao caso concreto que fêz objeto da discussão." Este primeiro passo dado pelo legislador brasileiro não parece ter alcançado êxito. Impaciente de qualquer demora na solução do pleito acêrca de direitos fundamentais garantidos pela Constituição e inexistindo na ordem jurídica ação adequada capaz de satisfazer às mais elementares exigências de tutela, procuraram os interessados socorrer-se de formas judiciais atípicas, não só para impedir a ameaça de violação iminente, como também para obter o pronto restabelecimento do direito ofendido. Serviam-se então quer dos interditos, visando proteger a chamada "posse de direito", quer do habeas. corpus, consideràvelmente ampliado em seu objeto, e já agora apto a abranger, além da liberdade de locomoção, ainda a liberdade de consciência, de pensamento e de reunião ${ }^{80}$. E'sta obra construtiva, para cujo triunfo cooperaram os mais distinguidos advogados, nomeadamente Rui Barbosa, realizou-a por algum tempo o Supremo Tribunal Federal, num esfôrço de adaptação de velhas formas de tutela jurídica às exigências da nova ordem, que

80. Cf. Luís E. DE BUENo Vidigal, Mandado de Segurança, p. 36 . e segs.; Pontes DE Miranda, Habeas Corpus, 1916, p. 136 e segs.; Pedro Lessa, Do Poder Judiciário, 1915, p. 268 e segs.; RuI Barbosa,. Coletânea Jurídica, p. 58 e segs.; Temístocles Cavalcanti, Do Man-dado de Segurança, p. 33 e segs.. 
reclamava medida mais pronta e eficaz para a proteção dos direitos do homem.

22. Não tardou a reação na doutrina e na jurisprudência. Contudo, o que fêz precipitar o aparecimento da tão esperada medida típica, protetora dos direitos individuais, foi, na realidade, a Reforma Constitucional de 1926, que para por côbro às controvérsias restringiu o âmbito do habeas corpus ùnicamente à liberdade de locomoção: “§ 22. Dar-se-á o habeas corpu's sempre que alguém sofrer ou se achar em iminente perigo de sofrer violência por meio de prisão ou constrangimento ilegal em sua liberdade de locomoção." 81 A êsse tempo a consciência jurídica nacional já estava preparada para definir um novo instituto, capaz de tutelar os direitos individuais de forma apropriada. Concorreram para isso, de um lado, as experiências puramente empíricas, feitas ao longo da primeira república e através dos interditos e dos habeas corpus; e de outro lado, as tentativas científicas levadas a efeito em obras de doutrina, e Congressos Jurídicos. O Brasil ia entrar, depois de 1931, num período de intensa reelaboração legislativa, não só atualizando as suas instituições políticas, mas também procurando abrir novo horizonte no domínio do direito constitucional. Realizou êste notável progresso, instituindo, em primeiro lugar, o mandado de segurança e, depois, a ação direta de declaração de inconstitucionalidade. 0 primeiro tende à proteção de direitos individuais; a segunda, à proteção da Constituição. O primeiro está impregnado ainda do acentuado individualismo jurídico do século XIX, a segunda é uma legítima conquista da política contemporânea de racionalização do poder. Esta é defesa direta, aquela, defesa indireta da Constituição. Cada qual, partindo de pontos distintos, concorre para um objetivo comum: a tutela da ordem jurídica constitucional.

81. Constituição Federal, art. 72, § 22. 
Do mandado de segurança.

\begin{abstract}
SUMário: 23. Acenos do mandado de segurança. Projeto GUdESTEU PIRES. Criação definitiva como garantia constitucional. 24. Natureza jurídica. Teorias. 25. Crítica às teorias. 26. Nossa opinião. 2\%. Sujeito ativo. 28. Sujeito passivo. 29. Extinção do direito. 30. Suspensão

liminar do ato. 31. Garantia de direitos individuais.
\end{abstract}

23. Ao que parece, a primeira sugestão destinada a regular essa forma judicial de tutela, distinta dos interditos e do habeas corpus, aparece no projeto de revisão constitucional, elaborada por Alberto Torres e publicada em apêndice na sua obra $A$ Organização Nacional. 0 art. 73 está assim redigido: "É criado o mandado de garantia, destinado a fazer consagrar, respeitar, manter ou restaurar, preventivamente, os direitos individuais ou coletivos, pủblicos ou privados, lesados por ato do poder público ou de particulares, para os quais não haja outro remédio especial. Parágrafo único. Êste mandado só poderá ser expedido, depois de ouvido o Conselho Nacional, ou outro órgão competente do Poder Coordenador, quando o direito lesado fôr de natureza essencialmente política, interessar diretamente a independência dos outros poderes públicos, ou quando a lesão resultar de atos daquêle poder. No exercício desta atribuição competirá ao órgão competente do Poder Coordenador decidir sob critério político e administrativo, o ponto de interêsse público ou governamental envolvido na causa". 82 No Congresso Jurídico de 1922, o Ministro Muniz Barreto propôs que se adotasse no Brasil um remédio semelhante ao amparo

82. Alberto Torres, A Organização Nacional, Rio, Imprensa Nacional, 1914, p. 367. 
mexicano ${ }^{83}$. 0 movimento em favor da criação do mandado de segurança cresce de vulto, especialmente depois da revisão constitucional de 1926, que restringiu o uso do habeas corpus à garantia da liberdade de locomoção, desvanecendo assim as esperanças dos que ainda confiavam nesse meio judicial para a defesa de direitos civis.

No dia 11 de agôsto de 1926, comemorativo da fundação dos cursos jurídicos no Brasil, o deputado Gudesteu Pires apresentou o projeto de lei $n .^{\circ} 148$, que instituia o mandado de segurança. Na sessão legislativa do ano seguinte, recebeu parecer favorável da Comissão de Justiça da Câmara, relatado por Afrânio de Melo Franco e subscrito por Anibal B. Toledo, Sérgio Loreto com restrições, Flores da Cunha, Horácio Magalhães, Raul Machado, Francisco Valadares e Luiz Pinto. Os deputados Matos Peixoto, Odilon Braga, Bernardes Sobrinho, Clodomir Cardoso e SÉrgio Loreto apresentaram substitutivos.

A Constituição Federal de 1934 inseriu no art. 113, $\S 33$, sob a rúbrica de "garantias de direitos" o mandado de segurança nestes têrmos: "Dar-se-á mandado de segurança para a defesa de direito, certo e incontestável, ameaçado ou violado por ato manifestamente inconstitucional ou ilegal de qualquer autoridade. O processo será o mesmo do habeas corpus, devendo ser sempre ouvida a pessoa de direito público interessada. $O$ mandado de segurança não prejudica as ações petitórias competentes." Embora o preceito constitucional fôsse autoexecutável, a variedade de questões, surgidas em conseqüência de sua aplicação, aconselhou uma regulamentação legal, o que se deu com a promulgação da lei n. $^{\circ} 191$ de 16 de janeiro de 1936. A experiência democrática dêsse instituto teve, porém, curta duração. A 10 de novembro de 1937 um golpe de estado substituiu a Constituição decretada pelo povo brasileiro por uma "Carta

83. Cf. Temístocles Cavalcanti, Do Mandado de Segurança, p. 175 . 
política", outorgada pelo Govêrno, a qual neṇuma referência fêz ao mandado de segurança. Todavia, o Decretolei n. $^{\circ}$ 6, de 16 de novembro de 1937, manteve o instituto, limitando-o em sua extensão e efeitos.

Voltando o país ao regime legal, a Constituição de 18 de setembro de 1946 incluíu-o entre as garantias de direitos individuais. Reza o art. 141, n. " 24: "Para proteger direito líquido e certo, não amparado por habeas corpus, conceder-se-á mandado de segurança, seja qual fôr a autoridade responsável por ilegalidade ou abuso de poder". Nos nossos dias o instituto está regulado pela Lei n. ${ }^{\circ} 1533$, de 31 de dezembro de 1951.

24. O mandado de segurança é uma ação judiciária, concedida ao titular de direito líquido e certo violado por ilegalidade ou abuso de poder. A sua característica fundamental consiste na possibilidade de compelir a administração pública a praticar ou deixar de praticar algum ato. Esta solução rompeu com a tradição do direito brasileiro, segundo a qual o inadimplemento das obrigações de fazer ou de não fazer se resolve em reparação pecuniária, isto é, na condenação em perdas e danos ${ }^{84}$. Anteriormente não se negava ao Poder Judiciário a competência para decretar a nulidade dos atos administrativos, violadores da lei ou da Constituição. Mas a sanção daí decorrente dava lugar, de ordinário, a uma indenização, não podendo o juiz substituir-se à administração. O mandado de segurança é, ao contrário, uma ação que confere ao titular do direito a possibilidade de obter a prestação in natura; mais vigorosa que tôdas as outras, esta ação judicial consegue não só a suspensão liminar ${ }^{85}$ do ato impugnado, como também a execução específica, repondo as coisas no estado anterior à ofensa.

84. Código Civil Brasileiro, art. 1056; Castro Nunes, Do Mandado de Segurança, p. 403.

85. Lei n.o 1533, art. 7, II. 
Reina entre os autores profunda controvérsia acêrca da natureza jurídica do instituto. 0 ilustre monografista CAstro Nunes sustenta que o mandado de segurança não objetiva um julgamento meramente declaratório. A eficácia da decisão é assegurada por seu cumprimento compulsório sob sanções legais. O mandado de segurança é, dêste modo, sempre executório. Êste caráter está implícito já na sua própria denominação. Considerado quanto à matéria sôbre que versa, o mandado de segurança é recurso administrativo; sob o aspecto jurisdicional, é remédio judiciário. ${ }^{86}$ Pontes DE Miranda atribui-lhe caráter tipicamente mandamental. Partindo de um conhecido conceito de KutNer, que permitiu depois a GoldschmidT incluir na classificação das ações segundo a natureza do provimento jurisdicional, o eminente processualista elevou à categoria autônoma tal tipo de sentença, que passa a figurar ao lado das declaratórias, constitutivas e condenatórias ${ }^{87}$. O professor LuIZ EuLálio DE Bueno Vidigal, numa monografia de alto valor científico, ensina que o mandado de segurança é um remédio que cabe ao particular para anular as medidas de execução, possessórias ou acautelatórias, que a administração pode, sem intervenção judicial, efetivar. $O$ mandado de segurança é, para usar de uma metáfora, o antídoto dessas medidas e por ser uma contra-medida de execução é que se denomina mandado de segurança e não sentença declaratória de segurança ${ }^{88}$. O mais recente tratadista da matéria, ОтноN Sidou, em livro profundo e bem informado, embora considere o mandado de segurança uma ação, de rito sumaríssimo, tendo por objeto a contenda

86. CASTro Nunes, op. cit., p. 68.

87. Pontes de Miranda, Comentários ao Código de Processo Civil, 2a. ed., vol. V, p. 147; GoLDSCHMIDT, Zivilprozessrecht, 2a. ed., 1932, $\S 15$ A, p. 61 e seg..

88. Luís Eulálio DE Bueno Vidigal, Mandado de Segurança, p. 199 e seg.. 
que resolve do modo mais peremptório ${ }^{89}$, atribuir-lhe, contudo, o caráter de interdito ${ }^{90}$.

25. Cada uma dessas teorias surpreende, sem dúvida, um aspecto da verdade, mas essa visão parcial e incompleta não permitiu que os seus ilustres autores compreendessem o instituto em tôda a sua extensão, fôrça e alcance. $O$ defeito capital das três primeiras teorias (pois a última não pode ser aceita por motivos diferentes) está em caracterizar a segurança pela executividade do seu mandado, o que significa explicar a natureza do todo por apenas uma de suas partes. Não se pretende com isso dizer que a executividade seja de pouca monta; mas ela é o posterius, do qual o prius é a sentença que reconhece o direito líquido $\mathrm{e}$ certo do autor ofendido por ato manifestamente ilegal ou de abuso do poder, praticado pela autoridade coatora. Entre um e outro há um nexo de interdependência, não sendo legitimo atribuir ao efeito importância maior que a causa que o determinou.

A quarta teoria procura, na idéia de interdito, o elemento característico do mandado de segurança. Não se pode contestar certa semelhança entre as duas figuras, consideradas especialmente sob o aspecto histórico. o direito romano, no período do ordo iudiciorum privatorum, assinalou várias diferenças entre as ações e os interditos, uma das quais consistia em que nestes o pretor dava imediatamente, atendendo à solicitação do autor, a ordem ou a proibição que já constava do edito. Mas quando o processo civil romano evoluiu para o sistema da extraordinária cognitio, suprimindo a separação in iure $\mathrm{e}$ in iudicio, os interditos perderam aquelas suas características, pelas quais se distinguiram pròpriamente das ações ${ }^{91}$. Modernamente não há necessidade de recorrer ao conceito de interdito para individuar a natureza

89. Отноn Sidou, Do Mandado de Segurança, p. 55.

90. OTHON SIDOU, op. cit., p. 31.

91. Emilio Costa, Profilo Storico del Processo Civile, p. 112. 
do mandado de segurança; a analogia que se quer vislumbrar em ambos, decorrente da medida liminar, é antes formal que substancial e por isso quase irrelevante, pois o elemento que concorre decididamente para distinguí-los não é a identidade da forma processual, antes a categoria diversa dos direitos tutelados pelas respectivas ações. A palavra interdito, reservou-a o legislador nacional para designar algumas ações possessórias ${ }^{92}$. O seu campo de aplicação abrange geralmente a ordem privada, operando na composição provisória do litígio; o mandado de segurança protege direito líquido e certo, violado pela autoridade pública. Concedida a segurança, o processo em tal caso compõe definitivamente o litígio.

26. O mandado de segurança é, a nosso ver, uma ação judiciária, que se distingue das demais pela índole do direito que visa tutelar. Para se entender bem êste enunciado, urge estabelecer, antes de tudo, uma gama dos direitos subjetivos materiais, que podem ser ajuizados. Elles se agrupam em três classes: a) a primeira é daqueles que hão de ser afirmados e provados judicialmente, sob pena de ser rejeitado o pedido formulado pelo autor (ex.: ação de desquite; de reintegração de posse; de anulação de contrato); b) a segunda é de alguns direitos, reconhecidos em documentos, que exprimem não só a certeza da obrigação, mas também a liquidez do seu valor (letras de câmbio, notas promissórias, duplicatas); c) e a terceira, que ocupa a posição mais elevada na escala, abrange direitos líquidos e certos, que, por sua clareza e evidência, não comportam discussão judicial a seu respeito. A ordem jurídica subministra ações diversas, que correspondem a cada uma dessas categorias de direitos. Para a primeira, a ação ordinária; para a segunda, a executiva; para a terceira, o mandado de segurança. A diferença entre os três remédios processuais está na intima correlação com os direitos que tute-

92. Código de Processo Civil, liv. IV, tít. XIII. 
lam. A necessidade de atos e têrmos se dá em grau maior na primeira, diminui na segunda e fica reduzido ao mínimo na última. O que determina a natureza da ação é, pois, a maior ou menor intensidade do direito tutelado; por se apresentar insuscetível de controvérsia na última hipótese, o legislador limitou ao indispensável o número de atos; por isso é que o mandado de segurança é ação de índole sumaríssima.

27. Sujeito ativo do mandado de segurança é o titular de direito líquido e certo, violado por ato ilegal ou de abuso do poder. $\mathrm{O}$ conceito de direito líquido e certo, embora se avizinhe do de título líquido e certo, com êle não se confunde; ao contrário, até se pode dizer que esta última idéia serve ùtilmente para extremar o conceito de direito líquido e certo. o título líquido e certo é aquêle que já contém uma declaração do direito constante do documento. Torna certa a obrigação e determinado o seu valor. Em virtude dessas características formais e substanciais, o legislador conferiu a essa categoria de direitos ação executiva, na qual o autor nada tem de demonstrar, porque o documento vale por si como prova da obrigação; se o réu tem matéria relevante para impugnar a eficácia do título, há de arguí-la na contestação, abrindo-se assim a discussão de mérito. De outro modo, a ação será julgada procedente, sem que o autor tenha de provar qualquer coisa.

$\mathrm{O}$ direito líquido e certo há de ser mais do que o título líquido $\mathrm{e}$ certo do ponto de vista substancial, embora seja menos do que êle do ponto de vista formal. Não é de sua essência que esteja representado por um documento; pode dizer-se que geralmente não o é, porque deriva da Constituição ou das leis. Mas, em compensação, para definí-lo, não basta dizer que se trata de direito translúcido, evidente, acima de tôda dúvida razoável, apurável de plano, sem detido exame nem laborio- 
sas cogitações ${ }^{93}$. Este conceito está repassado de acentuado subjetivismo, pois o que para um pode ser evidente e translúcido, para outra será duvidoso e controvertido. $\mathrm{O}$ que, a nosso ver, esclarece o conceito de direito líquido e certo é a idéia de sua incontestabilidade, isto é, uma afirmação jurídica que não pode ser séria e vàlidamente impugnada pelo poder público, que praticou um ato ilegal ou de abuso do poder. Ele tem, na realidade, dois polos: um positivo, porque se funda na lei; outro negativo, porque nasce da violação da lei. Ora, a lei há de ser certa em atribuir ao interessado o direito subjetivo, tornando-o insuscetivel de dúvida. Se surge a seu respeito qualquer controvérsia, quer de interpretação, quer de aplicação, já não pode constituir fundamento para a impetração de mandado de segurança.

28. Sujeito passivo do mandado de segurança é tôda autoridade responsável pela ilegalidade ou abuso do poder. A palavra autoridade está empregada na Constituição (art. $141, \S 24$ ) e na lei n. ${ }^{\circ} 1.533$ (art. $10^{\circ}$ ) para significar não só os órgãos do poder executivo, como também os do poder legislativo e judiciário. Os primeiros constituem a matéria normal do mandado de segurança, admissivel contra qualquer autoridade, desde o Presidente da República até o mais singelo funcionário. $O$ que $o$ artigo $1 .^{\circ}$ da Lei n. 1.533 realça é que o ato emane de autoridade, "seja de que categoria fôr e sejam quais forem as funções que exerça". Estendeu-se o benefício do mandado de segurança contra os atos de entidades autárquicas. "Consideram-se autoridade para os efeitos desta lei os administradores ou representantes das entidades autárquicas e das pessoas naturais ou jurídicas com funções delegadas do Poder Público, sòmente no que entende com

93. Carlos Maximiliano, Parecer (Jornal do Comércio, 28-VIII34); Castro Nunes, op. cit., p. 89. 
essas funções" 94 . O mandado de segurança é admissível também contra autoridades legislativas. $O$ que se deve entender por autoridade legislativa é matéria sôbre a qual não há uniformidade de vistas. A nosso ver, autoridade legislativa, entendida como sujeito passivo do mándado de segurança, é aquela a que toca a direção dos trabalhos dos corpos legislativos. Os atos que podem ser atacados por mandado de segurança são os atos administrativos das mesas das câmaras, não os atos legislativos ou leis, que traduzem a vontade colegial dos representantes do povo. Não é admissível mandado de segurança contra a lei considerada em tese ${ }^{95}$; mas, aplicada a lei, se ela fere direito individual, o mandado de segurança é meio idôneo para afastar a ilegalidade. 0 que se impugna é o ato administrativo executório decorrente da ilegalidade ou inconstitucionalidade da lei, que o Poder Judiciário deixará de aplicar no caso concreto.

A terceira categoria se refere à admissibilidade do mandado de segurança contra atos do poder judiciário. Êstes podem classificar-se em jurisdicionais e administrativos. Os primeiros são atos do ofício e concernem à função precípua de dizer o direito. Os outros são meramente administrativos e se referem, na maioria das vêzes, à nomeação, suspensão ou licença de funcionário. Contra êstes é admissível o mandado de segurança. Surge a dúvida quanto aos atos judiciais pròpriamente ditos. A doutrina dominante sob o regime da lei anterior admitia mandado de segurança contra decisões, para as quais não provia a lei recurso com efeito suspensivo. ${ }^{96}$ Todavia a lei em vigor, no art. $5 .^{\circ}$, contém uma redação defeituosa, dando lugar a interpretações discrepantes. Há autores que negam formalmente a admissibilidade de mandado

94. Lei n. ${ }^{\circ} 1533$, art. $1 .^{\circ}, \S 10^{\circ}$.

95. Cavalcanti, op. cit., p. 109.

96. Castro Nunes, op. cit., p. 121. 
de segurança contra decisões judiciais. ${ }^{97}$ A jurisprudência a admite, contudo, em sua mais larga extensão. ${ }^{98}$

29. A lei n. 1.533 prescreve, no art. 18 , que "o direito de requerer mandado de segurança extinguir-se-á decorridos 120 (cento e vinte) dias contados da ciência: pelo interessado do ato impugnado." O mandado de segurança é uma ação judiciária especial, que não visa à reparação pecuniária do direito ofendido, mas sim a evitar a realização ou a tornar sem efeito o ato administrativo, legislativo ou judiciário, praticado ilegalmente ou com abuso de poder. Contra a violação de direito líquido e certo, não deve fazer-se esperar a reação da ordem jurídica. Não sendo usado prontamente, perde a sua eficácia o remédio judicial. O prazo de 120 (cento e vinte) dias é contínuo e improrrogável.

Declara a lei que o direito de requerer a segurança se extingue. Evitou dessa maneira o emprêgo de palavras, conhecidas e usadas na lei e na doutrina, para exprimir o fenômeno de desaparecimento do direito, como prescrição, perempção e decadência. Apesar da clarividência do legislador, discutem ainda os intérpretes acêrca do entendimento do vocábulo. Castro Nunes pensa que a extinção do direito ou se dá pela prescrição (no sentido do direito civil) ou pela perempção (no sentido do direito processual). Ora, o que ai ocorre é mera perempção, não prescrição ${ }^{99}$. Diferente è a opinião de Temístocles Cavalcanti, para quem o prazo é de decadência ${ }^{100}$. O sentir unânime dos autores é que tal prazo não comporta interrupção.

97. Vidigal, op. cit., p. 118; CavalcantT, op. cit., p. 104; Buzaid, Do Mandado de Segurança em Revista de Direito Administrativo, vol. 44, p. 36; Ataliba Vianna, Limites ao Uso do Mandado de Segurança, p. 39.

98. Ac. do Sup. Trib. Fed., no mand. de segur. n. ${ }^{\circ} 6764$, rel. Min. VIlas BoAs em Rev. dos Tribunais, vol. 286, p. 933.

99. Castro Nunes, op. cit., p. 334.

100. Cavalcanti, op. cit., p. 140. 
A decisão proferida no mandado de segurança não impede que o requerente, por ação própria, pleiteie os seus direitos e os respectivos efeitos patrimoniais (lei 1.533, art. 15). Esse enunciado legal dá lugar a duas soluções: a) - a sentença pode denegar a segurança sem apreciar o mérito; b) - pode denegá-la entrando no exame e julgamento do mérito. Na hipótese prevista na letra "a", o pedido pode ser renovado, porque o juiz não entrou na apreciação do direito reclamado pelo impetrante. Na hipótese da letra " $b$ ", tendo o juiz entrado no exame do mérito, há que distinguir: ou concede ou denega a segurança. No primeiro caso, dada a categoria especial do direito invocado, a sentença transitada em julgado adquire os requisitos de imutabilidade e indiscutibilidade; no segundo, a decisão que, à míngua de elementos persuasivos, não pôde convencer-se da existência de um direito líquido e certo, deixa ressalvada ao interessado, a propositura de ação ordinária, na qual poderá afirmar e provar cumpridamente a pretensão ajuizada. É que, dado o caráter sumaríssimo do mandado de segurança, só é admissível nêle a prova documental.

30. O impetrante da segurança poderá requerer que o juiz suspenda liminarmente o ato impugnado, que deu motivo ao pedido, quando fôr relevante o fundamento, podendo resultar a ineficácia da medida, caso seja executado (art. 7. ${ }^{\circ}$, II, da lei 1.533). Esta apreciação feita ao início do processo tem caráter acautelatório, repondo as coisas no estado anterior, até decisão definitiva do pleito. A sua eficácia subsiste, mesmo na pendência de recursos interpostos contra as decisões denegatórias da segurança.

O sistema de recursos foi simplificado pela lei 1.533 , que há de ser harmonizada com preceitos da Constituição Federal. Da decisão proferida em mandado de segurança, em primeira instância, seja denegatória ou concessiva, cabe agravo de petição (lei 1.533, art. 12). Do julgamento proferido em segundo grau da jurisdição, sendo 
denegatória, o recurso admissível é o ordinário, previsto no art. 101, II, da Constituição Federal. No entender da jurisprudência, o recurso ordinário é amplo, podendo versar sôbre qualquer matéria, assim relativa à Constituição, como a leis federais, estaduais e municipais ${ }^{101}$; mas, sendo concedida a segurança pela última instância da justiça local, sòmente cabe recurso extraordinário se houver ofensa ao artigo 101, III, da Constituição Federal. Em ambos os casos, competente para julgá-los é sempre o Supremo Tribunal Federal.

31. O mandado de segurança é, pois, garantia constitucional de direito líquido e certo, violado por ato manifestamente ilegal ou abusivo do poder público. Nêle está expressa a mais solene proteção do indivíduo em sua relação com o Estado e representa, nos nossos dias, a mais notável forma de tutela judicial dos direitos individuais que, por largo tempo, foi apenas uma auspiciosa promessa.

\section{$\S 3.0^{\circ}$}

Da ação direta de declaração de inconstitucionalidade.

Sumário: 32. Defesa da Constituição. A ação direta de declaração de inconstitucionalidade no direito brasileiro. 33. Distinção entre mandado de segurança e ação direta.

32. A defesa da Constituição é feita, em direito brasileiro, por ação direta de declaração de inconstitucionalidade. A Constituição Federal inseriu no artigo $7 .^{\circ}$, VII, os seguintes princípios constitucionais: a) forma republicana representativa; b) independência e harmonia dos poderes; c) temporariedade das funções eletivas, limi-

101. Cf. Alfredo Buzaid, nota n.o $\mathrm{V}$ em Pedro Batista Martins, Recursos o Processos da Competência Originária dos Tribunais, p. 448. 
tada a duração destas à das funções federais correspondentes; d) proibição de reeleição de governadores e prefeitos para o período imediato; e) autonomia municipal; f) prestação de contas da administração; e g) garantias. do Poder Judiciário.

$O$ artigo $8^{\circ}$ da Constituição confere ao Procurador Geral da República legitimidade para submeter ao exame do Supremo Tribunal Federal a apreciação do ato ofensivo dos referidos princípios constitucionais. Não se. trata de mera representação, como se sustentou no Brasil ${ }^{102}$, mas sim de ação direta tendente a obter a declaração de inconstitucionalidade do ato, emanado de qualquer dos poderes, violador dos princípios constitucionais.

A distinção entre êste remédio constitucional e o mandado de segurança é substancial e profunda. Aquêle constitui defesa direta da estrutura orgânica do sistema constitucional brasileiro; êste, defesa direta da dogmática dos direitos individuais. Ambos concorrem para preservar a integridade da Constituição. Mas, enquanto a ação direta tem importância decisiva porque se funda. em ofensa capaz de abalar a estrutura do sistema constitucional, o mandado de segurança cinge-se à proteção. de direitos individuais, de limitada e estreita repercussão, não transcendendo os limites da esfera privada. A ação. direta, ao contrário, preserva a ordem pública.

A ação direta de inconstitucionalidade é meramente: declaratória. Acolhendo-a o Supremo Tribunal Federal, duas conseqüências resultam do julgamento: ou a decissão basta por si para restaurar a ordem jurídica violada; ou, quando não, o Congresso Nacional decreta a intervenção federal. A eiva de inconstitucionalidade atinge a: lei em seu berço. Ela, na verdade, não chegou a viver. Nasceu morta. Por isso, a sentença retroage os seus. efeitos, não à data da propositura da ação, mas ao mo--

102. Pontes DE Miranda, Comentários à Constituição de 1946, vol. I, p. 488; Revista Trimestral de Jurisprudência, vol. VI, p. 229; Archivo Judiciario, vol. 120, p. 420. 
mento em que foi promulgada a lei inconstitucional. Esta solução está conforme aos sãos princípios da doutrina. Uma lei não pode ao mesmo tempo ser e deixar de ser válida. As leis inconstitucionais são nulas desde a sua promulgação e se alguma vez chegam a ser executadas, embora inválidas, a nulidade decretada judicialmente produz o efeito ex tunc e não apenas depois da declaração judicial.

33. O mandado de segurança que visa à declaração de inconstitucionalidade e a ação direta, de que estamos tratando, distinguem-se ainda quanto ao modo de cassar ou suspender os efeitos da lei inconstitucional. O mandado de segurança não tem por objeto a declaração de inconstitucionalidade senão como o antecedente lógico e necessário de declaração judicial que há de versar sôbre a existência ou inexistência de relação jurídica. Por isso a apreciação sôbre a inconstitucionalidade ocorre incidenter tantum, pois o objeto principal do processo é a declaração de nulidade de relação jurídica de direito público. Conforme o art. 64 da Constituição Federal, reproduzido em numerosas Constituições estaduais, a lei declarada inconstitucional será suspensa; sendo lei federal, cabe ao Senado suspender-lhe os efeitos; sendo lei estadual, a competência é da Assembléia Legislativa ${ }^{103}$.

No caso da ação direta de inconstitucionalidade, cabe ao Congresso Nacional, que reune as duas Casas do Poder Legislativo, suspender a execução da lei, se essa medida bastar para o restabelecimento da normalidade no Estado; em caso contrário, poderá decretar a intervenção federal.

\section{Conclusão.}

De tudo quanto expusemos se infere que coube aos Estados Unidos o mérito de haver elaborado e incluído

103. Constituição Federal art. 64; Constituições Estaduais: de São Paulo, art. 21, letra $j$; de Santa Catarina, art. 22, n.o XII; do Rio 
na Constituição a primeira Declaração dos Direitos do Homem, em que se inspiraram as congêneres adotadas pela maioria das nações civilizadas. $O$ seu enunciado é ideològicamente verdadeiro, representando mais do que o ideal de um povo, o patrimônio comum de tôda a humanidade. Mas para não se reduzirem a meras proposições teóricas ou programáticas, era indispensável prover os direitos individuais de meios aptos à sua efetivação pronta e real. Os recursos atípicos, já usados com certo resultado, revelaram-se incompletos para assegurar uma tutela satisfatória. Há mais de um século os juristas mexicanos, sob a denominação de amparo, criaram um notável instituto, destinando-o a proteger especificamente os direitos individuais definidos na Constituição. Temendo, porém, que essa figura de tutela judicial pudesse ser restringida em seu alcance ou até suprimida por obra das legislaturas ordinárias, elevaram-na à eminência de garantia constitucional. 0 mesmo fêz o Brasil ao adotar, há um quarto de século, o mandado de segurança, que exerce função análoga à do amparo mexicano.

Mas êsses remédios constitucionais estão ainda impregnados do individualismo que lhes serviu de base, especialmente da filosofia jusnaturalista que pregava a existência de direitos do homem, anteriores e superiores ao Estado. $O$ pensamento jurídico contemporâneo, preocupado em racionalizar as funções do Estado, compreende que a grandeza da Constituição está não só em garantir os direitos individuais, mas também em obstar a qualquer agressão tendente a deturpar-lhe a estrutura orgânica, ou subverter-lhe o equilíbrio dos poderes. A defesa dos direitos individuais deve, pois, completar-se com a defesa da própria Constituição, porque aquêles não podem viver separados desta.

Grande do Sul, art. 46, n.o XVI; de Mato Grosso, art. 14, n.o VIII; de Goiás, art. 21, n.o X; do Espírito Santo, art. 19, n.o V; e do Ceará, art. 17, n.o XX. 
O Brasil procura contribuir para o progresso ao direito constitucional, oferecendo um novo tipo de ação, a que denominamos ação direta de declaração de inconstitucionalidade, com a finalidade precipua de defender a Constituição contra a ofensa aos seus princípios fundamentais; parte legítima para ajuizá-la é o Procurador Geral da República e competente para decidí-la, o Supremo Tribunal Federal. A declaração de inconstitucionalidade é pronunciada não incidenter tantum, mas como o objeto principal do processo. 